\title{
THE AQUA TRAIANA / AQUA PAOLA AND THEIR EFFECTS ON THE URBAN FABRIC OF ROME
}

\author{
Carolyn A. Mess \\ A Thesis Presented to the Faculty of \\ the Department of Architectural History \\ In Partial Fulfillment of the Requirements for the Degree \\ Master of Architectural History
}

May 2014

Cammy Brothers

Sheila Crane

John Dobbins 


\begin{abstract}
Infrastructure has always played an important role in urban planning, though the focus of urban form is often the road system and the water system is only secondary. This is a misconception as often times the hydraulic infrastructure determined where roads were placed. Architectural structures were built where easily accessible potable water was found. People established towns and cities around water, like coasts, riverbanks, and natural springs. This study isolates two aqueducts, the Aqua Traiana and its Renaissance counterpart, the Aqua Paola. Both of these aqueducts were exceptional feats of engineering in their planning, building techniques, and functionality; however, by the end of their construction, they symbolized more than their outward utilitarian architecture. Within their given time periods, these aqueducts impacted an entire region of Rome that had twice been cut off from the rest of the city because of its lack of a water supply and its remote location across the Tiber. The Aqua Traiana and Aqua Paola completely transformed this area by improving residents' hygiene, building up an industrial district, and beautifying the area of Trastevere. This study will analyze the spatial, aesthetic, social, political, and economic transformations that took place around the construction of the aqueducts.
\end{abstract}




\section{TABLE OF CONTENTS}

List of Illustrations $\quad$ iv

$\begin{array}{ll}\text { Introduction } & 1\end{array}$

Chapter 1: Font of Knowledge 9

$\begin{array}{ll}\text { Chapter 2: Il Fontanone } & 27\end{array}$

Chapter 3: Urbanism in Seventeenth-Century Rome 37

Conclusion: The End of the Line 49

Bibliography $\quad 52$

$\begin{array}{ll}\text { Illustrations } & 56\end{array}$ 


\section{LIST OF ILLUSTRATIONS}

Figure i.1: General Map of Rome with aqueducts and regional division [Source: Taylor, Public Needs and Private Pleasures, 18.]

Figure i.2: Coin depicting the construction of the Aqua Traiana [Source: Taylor, Rabun, Katherine Rinne, Edward O’Neill and Michael O’Neill. "A Grotto-Shrine at the Headwaters of the Aqua Traiana." Journal of Roman Archaeology, Vol.23 (2010): 358.]

Figure 1.1: Nineteenth-century engraving of the Cloaca Maxima. The Exit drain into the river Tiber, still exists today, but is now partly hidden by the modern Lungotevere Embankment, is clearly visible [just below the round Temple of Vesta [Source Hodge, Roman Aqueducts and Water Supply, 71.]

Figure 1.2: Aqua Paola Inscription [Photograph taken by author]

Figure 1.3: Route of the Aqua Traiana from Lake Bracciano [Source: Rinne, The Waters of Rome, 4.]

Figure 1.4: Entrance to the Aqua Traiana underneath the American Academy in Rome [Photograph taken by author]

Figure 1.5 A section of remnants of the Aqua Traiana making of the northern boundary of Villa Doria Pamphili, along the Via Aurelia Antica [Photograph taken by author]

Figure 1.6: Detailed map of the two separate branches of the Aqua Paola [Source: Rinne, The Waters of Rome, 142.]

Figure 1.7: Detail of Matteus Greuter's 1618 Map of Rome [Source: Frutaz, A.P, Le Piante di Roma, $2^{\text {nd }}$ vol., Roma, 1962, Tav. 291.]

Figure 2.1: Aqua Paola's mostra fountain, Il Fontanone [Photograph taken by author]

Figure 2.2 Detail of Matteus Greuter's 1618 Map of Rome documenting Il Fontanone [Source: Frutaz, A.P, Le Piante di Roma, $2^{\text {nd }}$ vol., Roma, 1962, Tav. 291.]

Figure 2.3 Detail of Francesco de Paoli's 1623 map of Rome documenting and labeling Il Fontanone [Source: Frutaz, A.P, Le Piante di Roma, $2^{\text {nd }}$ vol., Roma, 1962, Tav. 294.]

Figure 2.4: Fountain of Moses, designed by Domenico Fontana [Photograph taken by author]

Figure 2.5: The original conception of the Fontanone, engravings by Giovanni Battista Falda [Source: Heilmann, "Acqua Paola and the Urban Planning of Paul V Borghese," 657.]

Figure 2.6 Il Fontanone as redesigned by Carlo Fontana in 1690 [Source: Symmes, Fountains: Splash and Spectacle: 37.$]$ 
Figure 3.1: The original plan of the Aqua Paola's distribution system [Source: Heilmann, "Acqua Paola and the Urban Planning of Paul V Borghese," 663.]

Figure 3.2: A modern day photograph of workers replacing sampietrini, they still utilize the road construction method from the Renaissance [Source: Rinne, The Waters of Rome, 209.

Figure 3.3: Leonardo Bufalini's map of Rome, 1551 (the area of Trastevere) [Source: Frutaz, A.P, Le Piante di Roma, $2^{\text {nd }}$ vol., Roma, 1962, Tav.169.]

Figure 3.4: Francesco de Paoli's map of Rome, 1623 (the area of Trastevere) [Source: Frutaz, A.P, Le Piante di Roma, $2^{\text {nd }}$ vol., Roma, 1962, Tav. 294.]

Figure 3.5: Etching of the Scoglio Fountain in the Vatican Garden [Top, Source: Rinne, The Waters of Rome, 142]; Modern day picture of the fountain in the Vatican Gardens [Below, photograph taken by author's sister, Sara Mess]

Figure 3.6: Route of the Aqua Paola's Janiculum Branch [Source: Rinne, The Waters of Rome, 151.] 


\section{INTRODUCTION}

When walking around the city of Rome it is apparent the city is designed to showcase vast amounts of water. From an aerial view, Rome is split by the Tiber's winding path, with multiple bridge crossings. Zooming in, it is impossible to miss the streetscape and the multitude of fountains dotting the urban landscape. Water plays an important visual role in Rome, but its real importance is hidden underground, in the subterranean infrastructure that allowed this city to flourish. As the city has grown over many centuries, this network of aqueducts, pipes, and cisterns supplied the city with life. While infrastructure has always played an important role in urban planning, the focus of urban form is often the road system and the water system is only secondary. This is a misconception as often times the hydraulic infrastructure determined where roads were placed. Architectural structures were built where easily accessible potable water was found. People established towns and cities around water, like coasts, riverbanks, and natural springs. By isolating the aqueducts of the Aqua Traiana and the Aqua Paola, this study will analyze the design, social, and aesthetic transformation that took place in the Transtiberium area of Rome, located west of the Tiber, in two periods of major growth.

While there has been much written about the aqueducts, fountains, and piping network of Rome's water system, the parts of system on the outskirts of the city, like the Aqua Traiana and its modern day extension, the Aqua Paola, have been neglected. The Aqua Traiana was the only functioning aqueduct that supplied the Transtiberium region of Rome, which was found on the western side of the Tiber. The majority of Rome's water system is found on the eastern side of the river where most of Rome's population lived, and because of this it was more thoroughly documented at the time of its construction and revitalization. Scholars such as Rodolfo Lanciani and Thomas Ashby, and more recently Rabun Taylor and Katherine Rinne, have written 
extensively about the aqueducts and the general water infrastructure found on the eastern side of the Tiber.

From the examination and analysis of Rome's water system over the last five hundred years, the research encompasses a wide range of topics from documenting the system's plan to looking at its aesthetic value to examining what the water flow reveals about social status in a specific area. Parts of this system, including aqueducts like the Aqua Traiana, which was then replaced by the Aqua Paola, are often skimmed over because there is not as much information about the areas it services.

Originally built under Emperor Trajan, the Aqua Traiana aqueduct served the west side of Rome, most notably the area of Transtiberium (area XIV on Figure i.1), then crossed the Tiber into the eastern half of the city to Oppian Hill where Trajan's Baths were located. This aqueduct was constructed so that Trajan's bath complex was supplied with an adequate amount of water, but it had the additional benefit of providing water to the western bank of the Tiber which allowed this area to become more desirable to a larger population. Before the aqueduct, individuals living in Transtiberium did not have enough potable water, forcing them to live in unsanitary conditions rife with disease because of sewage and trash being dumped into their main water source. Only a handful of ancient sources about the Aqua Traiana aqueduct exist, most notably a coin issued between 109 and 117 under the Emperor Trajan (Figure i.2)

Ancient coins act as a source because they depict important events and are often released in commemoration of that event, which can lead to an approximate date. Most of the information on the Aqua Traiana comes from the archeological excavations conducted on its remaining segments. Additional information, specifically about the aqueduct's path, appears when analyzing the Aqua Paola, built by Pope Paul V between 1607 and 1612, which followed 
the Aqua Traiana's path and also incorporated materials from the ancient aqueduct. The Aqua Paola and the fountains built along its line played an integral role in the urban development of Rome during the early seventeenth century.

Much like the water running through the current aqueducts of Rome's vast hydraulic network, this thesis is divided into three chapters, each of which highlights an important component that contributed to the urban development of the area of Transtiberium, modern day Trastevere. The first chapter delves into the history of the area and gives an overview of how it transformed in the first century and the seventeenth century with the construction of the aqueducts. The Aqua Traiana is first introduced as a part of Rome's vast hydraulic system, beginning in Ancient Rome with a brief introduction into its water network. This is followed by a clear and concise history of the Aqua Traiana's planning, construction, and significance from $103 \mathrm{CE}$ to $537 \mathrm{CE}$. The chapter then fast-forwards, performing the same analysis for the Aqua Paola, which is considered a revival of the Aqua Traiana. This in-depth exploration of the aqueducts' histories lays the necessary foundation for understanding how this single aqueduct fits into Rome's vast system of water. This analysis illustrates how the addition of these aqueducts, within their respective times, structurally, socially, and aesthetically transformed this remote area to the west of the Tiber into a desirable location.

The second chapter concentrates on the mostra fountain, Il Fontanone, found at the terminal end of the Aqua Paola. It contains an overview of the construction of the fountain and introduces how Pope Paul V used this fountain as a political tool for his ambitious large-scale urban plan for the western bank of the Tiber River. It is important to isolate the fountain and expand upon its historical significance within the time period it was constructed because it not only demonstrates Pope Paul V's influence in Rome during this time, but it also is a key factor in 
Trastevere's design. Everything about Il Fontanone, including the area in which it was placed, its overall design, and the materials used to construct it was intentional, calculated, and deliberate. Much of the construction that took place during his papacy was on the west bank of the Tiber, thus this fountain along with the water it supplied to the city of Rome represented the lynchpins of Pope Paul V's grand urban development. This area, left to deteriorate in the Middle Ages because of the lack of aqueduct maintenance, represented an area of land that was underutilized and underdeveloped.

The last chapter focuses on how the Aqua Paola and its fountain played a pivotal role in urban developments within the region of Trastevere. In particular, it examines infrastructure and aesthetic urban planning projects that were directly related to the aqueduct's existence in this region. This analysis illustrates the Aqua Paola's position as one of both historic and social importance, seen in everything from Trastevere's road layout to where both public and private fountains were placed. This is important because this urban transformation represents the second time in history that Trastevere changed from an unsanitary, remote, and desolate location, into a more hygienic, better connected, and desirable area.

Through the work, approaches, and methodologies of three leading scholars in Roman water-Rabun Taylor, Katherine Rinne, and Christoph Heilmann — it is readily apparent that this aqueduct played an integral role in the formation of the area of Trastevere as it is known today. Rabun Taylor's interests within the classical world are broad and approached through a multidisciplinary lens. His book, Public Needs and Private Pleasures, details the historical, social, and economic effects of the ancient aqueducts on the city of Rome. It gives a clear and concise history of the ancient aqueduct system, including its planning, construction, and impact on Rome. His research was helpful to this project because not only in explaining the engineering 
behind these ancient structures, but also in shedding light on the social impact of the aqueduct. He also included extant research pertaining to the Aqua Traiana. Taylor's discussion of the overall picture of Rome's ancient hydraulic system and his process of analysis formed the foundation for this thesis. His broad scope takes into account the entirety of the ancient water infrastructure and how it functioned within Roman society. His conclusions viewed water infrastructure's social component as well as its technical aspect. Even though this thesis concentrates on a single aqueduct, Taylor's methodology can be applied to the smaller scope of the Aqua Traiana and the Aqua Paola to see how society formed and transformed around the line.

Approaching the water system of Rome through the lens of social science, in this case anthropology provides a basis to analyze the network, not as a feat of engineering, but as an integral part of the city. Taylor emphasizes the necessity of water in the ancient world, as well as the impact water delivery systems had on daily life. He analyzes the infrastructure of ancient Rome and the pressing urban problems surrounding them in Roman society, ranging from water legality to environmental concerns. His study of this vital network focuses on how each of the individual aqueducts impacted Rome. ${ }^{1}$ Taylor's focus on the social impact the ancient aqueducts had on the city created a solid foundation for comparison of the Aqua Traiana to its modern counterpart, the Aqua Paola. Though they were constructed many centuries apart, they fulfilled the same civic, functional, and developmental roles. Both were constructed using similar techniques, were used as a political tool by the rulers who created them, contributed to the economy of Rome, influenced urban development, and supplied the area west of the Tiber with clean potable water.

\footnotetext{
${ }^{1}$ Rabun Taylor, Public Needs and Private Pleasures: Water Distribution, the Tiber River and the Urban Development of Ancient Rome (Studia Archaeologica. Vol. 109. Roma: L'Erma di Bretschneider, 2000$), 11$.
} 
While Taylor focuses on ancient aqueducts, Katherine Rinne concentrates on this vast network's significance in Baroque Rome. Rinne's book, The Waters of Rome: Aqueducts, Fountains, and the Birth of the Baroque City, provides a fresh perspective on Rome's hydraulic network. She focuses largely on how the fountains impacted the areas in which they were constructed. This creates a great opportunity for comparison to Taylor's social analysis of the ancient aqueducts, and introduces aesthetic and civic dimensions that are important in Rome's urban transformation in the early seventeenth century.

While writing The Waters of Rome, Rinne spent four months walking Rome street by street, documenting, sketching, and mapping every possible water outlet. Using her data, she then created a detailed topological map of Rome with an overlay of all of the water features. The mapping process gave her an intimate understanding of not only the elements that comprise this vast system, but also how they function as a larger network within the city. The map allowed her to approach this topic from a different angle than previous scholarship, which isolated the separate water components found in Rome. The scholarship pertaining to the fountains in Rome are numerous, but Rinne is the first person to study how the fountains were linked through the three main aqueducts supplying them — the Aqua Vergine, Aqua Paola, and the Aqua Feliceinstead of viewing them as individual structures. The map revealed how Rome's topography and steep grades affected the designs of the fountains. She concludes that because there was a high demand for clean potable water, aqueducts defined where the city could grow and by how much.

Rinne concentrated largely on the aqueducts found within the city wall, but this methodology and the systematic examination can be applied to the Aqua Traiana and the Aqua Paola. Isolating this aqueduct, and therefore a specific area of Rome, created a suitable scope in which to study the growth and development of this particular area from antiquity through the 
Baroque period. In rapidly expanding cities such as Rome during the Renaissance, the aqueducts engineers acted as city planners, much like the highway system in today's society. Since a supply of usable water was not always available, when an additional aqueduct line was constructed an area would be destroyed and then rebuilt and formed around the new aqueduct's path. Rome's water system facilitated urban development, allowing the city to be built around these three aqueduct lines. Rinne analyzes how making water a readily available commodity is a catalyst of urban form and social change. More fountains meant more access to fresh water for drinking, laundry, and improved hygiene, driving population growth. It also had a large impact on court life, as fountains represented wealth, and patrons were eager to use them to show off their riches. This symbolism is an important factor when analyzing the fountains found along the pathway of the Aqua Paola.

Like Rinne, the German art historian Christoph H. Heilmann's research like Rinne's focuses on Roman Baroque; however unlike Rinne, he analyzes how this architecture and infrastructure affected the layout of the urban areas of Rome. His work in important to the discussion about Trastevere's transformation in the seventeenth century because he focuses on Pope Paul V's urban plan and how it effected the area of Trastevere. In his article, Aqua Paola and the Urban Planning of Paul V Borghese, he analyzes the construction of these roads, and hypothesizes that the Aqua Paola and its fountain had a more significant impact on the planning in the area of Trastevere than previously thought. While the article may be difficult to follow because of the lack of topographical information, the foundation he laid opened up an avenue of research to examine in detail the effects, both structurally and socially, of the Aqua Traiana and the Aqua Paola in the area of Trastevere. These particular aqueducts, though separated by 
centuries, served the same purpose and were essential to the growth of this particular area of the city during the time of their construction.

Using the Aqua Paola, during the time it was rebuilt under Pope Paul V, as an example of water infrastructure's influence on urban design will help reveal another layer of understanding in the continuing story of Rome's water system. This aqueduct and its fountain are not only an engineering feat, but also a significant component in Rome's urban landscape, both in the city's past and present. 


\section{CHAPTER 1 FONT OF KNOWLEDGE}

The city of Rome is known for its layered history; which is both complex and difficult to comprehend. Found nestled within these layers is the subterranean hydraulic system.

Unearthing the network of water allows historians to zoom in to parts of the network that give a physical and theoretical foundation for the developments for the regions of Rome. This project analyzes the Aqua Traiana, a single aqueduct in a larger system, and its Renaissance counterpart, the Aqua Paola and the Paola's mostra fountain, examining how construction of these aqueducts and fountains directly correlate to the urban form of what is modern day Trastevere. These two aqueducts, though constructed fifteen centuries apart, had the same social, political, economic, and aesthetic effects on the area west of the Tiber.

Unraveling the history of Rome's entire water infrastructure is difficult due to the large area the network covers and the number of components that make up the system. This complex infrastructure consisted of eleven aqueducts (Figure i.1) that split into multiple channels, which were further divided by lead pipes. Each of these, in turn, led to a systematic distribution of water controlled through a variety of fountains, villas, and gardens both public and private. This network ensured the entire city of Rome, both urban and suburban, received an adequate volume of usable water that was needed for everyday activities such as hygiene, drinking, and laundry.

Most of the information about this system, outside of the archaeological realm, is data compiled by Sextus Iulius Frontinus in his treatise, De aquaeductu. Frontinus served as Rome's water commissioner during the reign of Nerva (96-98 CE) and during the early years of Trajan (98-117 CE), and he took the initiative to compile a detailed documentation of Rome's water 
infrastructure. ${ }^{2}$ Within the course of two or three years Frontinus completely transformed the water distribution system in the city. According to Taylor, Frontinus surveyed:

the entire aqueduct network for unauthorized and inadvertent diversions tapped new sources for one of the major aqueducts, and separated the waters of aqueducts that had been mixed. By this time he had also begun to build new distribution tanks, fountain basins, and arcades throughout the city, and to ensure all the urban regions, and even all the hundreds of public fountain basins, were served by at least two aqueducts. ${ }^{3}$

Frontinus's analysis mapped the entire existing water infrastructure and included a range of information about the aqueducts, from the specific distribution area of each aqueduct, to a brief history of the individual aqueduct's line. Frontinus's treatise also provided evidence that Roman citizens were tapping the existing aqueducts and using the water for their personal needs, something that was considered illegal in ancient Rome. As significant as De aquaeductu was, it was completed shortly after Trajan's accession, and therefore does not include many of the hydraulic projects, such as the Aqua Traiana, the public bathing complex, or the fountains that were constructed under his rule. There is mention of a new water distribution scheme, which is likely referring to the Aqua Traiana; however the Traiana is not mentioned by name, so it is unclear as to whether this scheme refers to the early planning stages of the Traiana or the general upkeep of the existing systems. Because there is no record of an official survey for the Aqua Traiana, Frontinus's process of analysis will be the primary source used when examining this aqueduct. Examining the different aspects of the Aqua Traiana such as engineering, distribution, and social transformation, helps scholars create a detailed picture as to why it was constructed, the impact it had on the urban form of Rome, and how it fits into the overall water system.

The Aqua Traiana, constructed from $103 \mathrm{CE}$ to $109 \mathrm{CE}$, was introduced into Rome's network to alleviate problems dealing with supply, distribution, and volume of water. First, the

\footnotetext{
${ }^{2}$ Taylor, Public Needs and Private Pleasures, 16.

${ }^{3}$ Taylor, Public Needs and Private Pleasures, 16.
} 
city of Rome was expanding and needed additional water sources. The nine aqueducts that supplied the city before the Traiana was built did not reach all of the residential areas and, with the city's growth, Rome's water system had to increase to cover more ground.

In ancient Rome, the pilfering of water was a major governmental concern. Individuals would break the water line, thereby diminishing the volume slightly while significantly decreasing the pressure. Since an aqueduct's ability to function relied on precise engineering that took into account topography, gravity, and pressure, tampering with one of these values drastically changed the functionality of the aqueduct. If this happened multiple times on a single line, the components found further down the line would suffer because there was not enough pressure to carry the water to the end. Often this meant that the entire community suffered, as civic basins were the final destination for the water, and without the proper pressure there would not be enough water to supply the demand of the public. In order to counteract this activity, Trajan stated that the volume of water to be gained from the introduction of a new aqueduct would offset the volume lost from tapping into the other lines. ${ }^{4}$ Since it was difficult to stop the illegal tapping of the aqueducts, the implementation of this new aqueduct greatly benefitted the people living in Transtiberium.

The second factor placing strain on the volume of Rome's existing water supply was the construction of Trajan's Bath complex. Its construction began during Emperor Domitian's reign (81-96 CE), but was halted with the fire on Oppian Hill, where the complex was located, in 104 CE. ${ }^{5}$ It is likely that both the bath complex and the aqueduct supplying it were propagandistic gifts from Trajan to the city of Rome and her people, representing a portion of the wealth acquired from the triumph of the Dacian Wars (101-102 CE and 105-106 CE). Trajan likely

\footnotetext{
${ }^{4}$ Taylor, Public Needs and Private Pleasures, 243.

${ }^{5}$ Taylor, Public Needs and Private Pleasures, 243.
} 
decided to revive the bath project after the construction of the aqueduct had begun, and this complex certainly played a significant role in determining the aqueduct's course. ${ }^{6}$ Since the complex was located within the city walls on the eastern side of the river, sitting atop Oppian Hill, Trajan needed to build a new aqueduct that crossed the Tiber in order to ensure his imperial baths were supplied with ample amounts of water.

Lastly, Trajan sought to rectify the problem of the lack of water distribution in the Transtiberium with the Aqua Traiana. The Transtiberium was the fourteenth region identified by Emperor Augustus's survey in seven BCE. In antiquity, it was the only populated area located on the west bank of the Tiber, and therefore was not connected to Rome's vast water network found on the eastern side of the river. ${ }^{7}$ There was only one other ancient aqueduct that ran anywhere close to this region, the Aqua Alsietina, built by Emperor Augustus in the first century BCE. The water brought by this aqueduct had insufficient volume for the area and was not potable. By the time the Aqua Traiana was constructed, Frontinus described the Aqua Alsietina's flow as "little more than an irregular trickle."

Though it is speculated that the main reason for the construction of the Aqua Traiana was to bring ample amounts of water to Trajan's bathing complex, the fact that the Traiana resolved the lack of clean water in the Transtiberium is an additional benefit. The river, and by extension the spring and wells found in this area, could not be used as potable water because the Cloaca Maxima, the largest ancient Roman sewer, exited into the Tiber through a drain. (Figure 1.1) The water drawn from the wells in this area was "river water that had percolated sideways, but in

\footnotetext{
${ }^{6}$ Taylor, Public Needs and Private Pleasures, 17.

${ }^{7}$ Jérôme Carcopino, Daily Life in Ancient Rome: The People and the City at the Height of the Empire, (New Haven: Yale University Press, 1940) 13-14.

${ }^{8}$ Taylor, Public Needs and Private Pleasures, 176.
} 
its passage through the soil it must have been at least partly filtered."9 Passing through the soil certainly made the well water more filtered than the water straight from the Tiber, but it was still heavily polluted. Because of this, residents relied on the aqueducts found on the eastern side of the river for potable water. The addition of the Aqua Traiana's path crossed through this area ensured the Transtiberium had a steady supply of usable water. Since there was only one region found on the western side of the river, the Aqua Traiana's water provided the potential for urban growth on the western side of the Tiber.

While it is now accepted that this aqueduct serviced areas of Transtiberium, this was not always the case. During the Middle Ages the link of the Traiana to Transtiberium was lost as the aqueduct fell into disrepair. ${ }^{10}$ At that time, the only known ancient aqueduct that went to that area was the Aqua Alsietina. When Pope Paul V revitalized the Aqua Traiana, he thought the ancient aqueduct line he was following was that of the Alsietina and not the Traiana. The Latin inscription on the Aqua Paola fountain shows this discrepancy. ${ }^{11}$ (Figure 1.2) This inscription citing the wrong ancient aqueduct as the newly restored aqueduct's source water caused problems when trying to analyze the path of the ancient aqueduct. Even though the two ancient aqueducts' paths ran in close proximity to one another, they had different sources. The Aqua Alsietina's was Lake Martignano, a smaller lake found east of Lake Bracciano, which is the main source for the Aqua Traiana.

Even without evidence of the exact path, archaeologists found ruined segments, both above and below ground, from which they were able to approximate the path of the Aqua

\footnotetext{
${ }^{9}$ Trevor A Hodge, Roman Aqueducts and Water Supply (London, England: Gerald Duckworth and Co., 1991 ), 71.

${ }^{10}$ Taylor, Public Needs and Private Pleasures, 208.

11 The Latin inscription reads "Paulus Quintus pontifex maximus aquam in agro Braccianensi saluberrimis e fontibus collectam veteribus Aquae Alsietinae ductibus restitutes novisque additis XXXV ab milliario duxit." This is roughly translated to "From the thirty-fifth milestone in the region of Bracciano, Pope Paul V brought water drawn from the ancient sources of Aqua Alsietina, which he restored, and from additional new ones. Note: All translations in this thesis are by the author unless otherwise specified.
} 
Traiana. Tapping into the springs on the northern and western slopes above Lake Bracciano, it passed near the modern town of Trevignano and proceeded to curve around the eastern edge of Lake Bracciano until it reached the valley of Arrone. There, because of the topographical changes, the aqueduct became subterranean for the majority of its course to Rome. Passing near the ancient city of Veii, the aqueduct's channel parallels Via Cassia (south of La Storta), and then Via Trionfale (south of Giustiniana.) ${ }^{12}$ The aqueduct arrives just north of the town of Rome on the Janiculum Hill. (Figure 1.3) Throughout its course, the Traiana supplied as many as thirteen other towns on its path from the springs around Lake Bracciano. It is unknown whether this pathway was engineered to supply these rural areas with water as well, but considering the volume and pressure of water that reached Rome, these it can be hypothesized that they were factored into the plan.

A number of the Traiana's sections have been found through archaeological excavations, all with varying heights, widths, materials, and construction styles. This assortment of ruins shows the aqueduct was built quickly, with little concern for its aesthetic appeal. There are two places, one subterranean and one above ground, where these remnants are well preserved. The best-preserved subterranean section is found under the American Academy in Rome, where visitors to the Academy can enter it through a removable tile in the basement floor. (Figure 1.4) This underground section is important because it confirms the path of the aqueduct before it headed down to the area of Transtiberium. While this section is the most complete subterranean part of the aqueduct, the most visible above ground remnants are found beyond Porta San Pancrazio along the northern boundary of Villa Doria Pamphili, along the Via Aurelia Antica. (Figure 1.5)

\footnotetext{
${ }^{12}$ Peter J. Aicher, Guide to the Aqueducts of Ancient Rome (Wauconda, Ill: Bolchazy-Carducci Publishers, 1995), 44.
} 
Fragmentary as they are, these ruins show typical utilitarian features of a Trajanic style aqueduct. The bulk of the channel is constructed using opus caementicium-Roman concretewith an inlay of square tufa, a type of igneous rock, stones for facing. ${ }^{13}$ In addition, the inside walls were faced in opus reticulatum, a common construction technique consisting of brickwork resembling a tight fishnet pattern. In that time period, the channel would have been sealed with a thick layer of opus signinum, a plaster made of small pieces of broken up tile mixed with mortar, in order to make a conduit that was smooth as well as waterproof. These details combined with the lack of ornamentation, and relatively thick, unornamented piers make it the most utilitarian looking of the ancient aqueducts. Since the majority of this above ground aqueduct was located outside the city walls, its functionality took priority over ornamentation. Also, with the western side of the Tiber and Trajan's bath complex relying on the water supply of this aqueduct, it was imperative that the Aqua Traiana was constructed quickly. Though it was constructed in six short years, the expert craftsmanship and frequent repairs kept this aqueduct functioning for centuries to come.

The point at which the ancient aqueduct entered the city of Rome - the Janiculum Hillis evident from the ruins of grain mills found on this spot. The water that flowed from the aqueduct was used to power the mills found on its slope. According to archaeologists Albert Van Buren and Gorham Stevens, these mills "derived their supply of water from the aqueduct... [and] with their reservoirs full, could be cut off entirely from the aqueduct in case the latter was in need of repairs; the storage space in the reservoirs would then permit the mills to be used for some time while the repairing was being carried on." ${ }^{\text {14 }}$ The mill reservoirs were important

\footnotetext{
${ }_{13}^{13}$ Aicher, Guide to the Aqueducts of Ancient Rome, 78.

${ }^{14}$ Andrew Wilson, "Machines, Power, and the Ancient Economy," The Journal of Roman Studies, vol. 92, (2002): 12-13; Albert William Van Buren and Gorham Phillips Stevens, "The Aqua Traiana and the Mills on the Janiculum," (Memoirs of the American Academy in Rome 1, (1915)), 61.
} 
because it meant the mills could run even if there was not enough water being brought in by the aqueduct, ensuring the mills' steady production and continuing economic contribution to Rome.

These reservoirs were positioned here because once the aqueduct reached the hill it was divided into two separate channels. These were categorized by the upper and lower segments; the upper supplying the mills and the lower heading down to Transtiberium. There is an important passage from the life of Pope Honorius II which describes this spilt: "the channel that brings water from the Lacus Sabatinus and, downstream from it [i.e. the mill], the channel that conducts water to the Tiber." ${ }^{\prime 15}$ Once the mills were serviced, the remaining water was taken down the hill, via a gravity-flow channel. After its opening, the multiple demands placed on this aqueduct made the Traiana one of the most depended on aqueducts of the eleven found in Rome. It provided water for the residents in Trastevere and the Janiculum, the industrial district around the port, and the Baths of Trajan.

Since the east bank of the river was so crowded, the wealthy Romans found moving to the somewhat isolated rural area of the Janiculum was peaceful, and soon the "demographic and economic base was the political weight of many of Rome's most powerful families, [was] physically manifested in the villas and gardens on the Janiculum." ${ }^{16}$ A completely new suburban area was formed around the Aqua Traiana's path and with it the population of found on the western side of the Tiber. Closer to the river banks, despite the region's unglamorous reputation, most of Rome's industrial district was found in the Transtiberium. While Rome produced few finished goods for export, it generated vast quantities of pottery, wine, and olive oil for its own

\footnotetext{
${ }^{15}$ The full passage from the life of Honorius reads, "Et ibi constutuit mola in murum in loco Traiani, iuxta murum civitatis, et formam qui deducit aqua in lacum Sabbatinum et sub se formam qui conducit aqua Tiberis." This Latin was emended to "Et idi constituit molam in loco Traiani iuxta murum civitatis, et formam, quae ducit aquam a Lacu Sabatino, et sub se formam, quae conducit aquam ad Tiberim. " Davis, Raymond, The Lives of the Eighth-century Popes (liber Pontificalis): the Ancient Biographies of Nine Popes From Ad 715 to Ad 817 (Liverpool: Liverpool University Press, 1992), 152, n. 109.

${ }^{16}$ Taylor, Public Needs and Private Pleasures, 248.
} 
population. Taylor states, “... evidence of Rome's productivity resides in the Transtiberium, either in the form of physical plane (mills and factories) or human resources (many resident tradesmen and laborers [live in this area].) ${ }^{\prime 17}$ With the addition of clean usable water, supplied by the Aqua Traiana, more craftsmen, and by extension their businesses, moved to the less populated area of Transiberium and closer to the port.

Because of its growing industrial population, the Transtiberium gained administrative importance. Most of ancient Rome's raw goods came up the Tiber on barges, which were towed by slaves. Since there were no river crossings between the other ports and Rome all the goods were "offloaded either directly at Porta Ripa Grande in the Transtiberium, or else at Pietra Papa and then carted up the via Portuensis to the Transtiberium."18 This newly found prestige made the area of Transtiberium a major economic point in Rome.

These ports and suburbs relied mostly on the Aqua Traiana because of the large volume of water it supplied. While both of the ancient aqueducts, the Aqua Alsietina and the Aqua Traiana, both have sources drawn from north of Rome, only the Traiana enters into Rome on the Janiculum Hill. Raffaello Fabretti, an Italian antiquarian, reestablished the connection between the Traiana and Transtiberium region in $1680,{ }^{19}$ however, it was not confirmed until 1830 with the discovery of an in situ inscription, found 10 miles north of Rome. This plaque mentioned Trajan's purchase of the land and the dedication date (109 CE) of the aqueduct. ${ }^{20}$ A century later, two independent discoveries, highlighted by scholar Herbert Bloch, further connected the Aqua Traiana and the Transtiberium area. The first of these was made available in 1932 by Italian archaeologist Guido Calza. Calza wrote:

\footnotetext{
${ }^{17}$ Taylor, Public Needs and Private Pleasures, 247-248.

${ }^{18}$ Taylor, Public Needs and Private Pleasures, 248.

${ }^{19}$ Taylor, Public Needs and Private Pleasures, 208.

${ }^{20}$ Taylor, Public Needs and Private Pleasures, 208.
} 
a fragment of the Fasti Ostienses which deals with events of the years 108-113 AD. It is well know that these Fasti are excerpts form the Acta Urbis, a source of highly official character, and that their trustworthiness is almost unique. This is particularly true in matters concerning the dedication of buildings, which naturally were registered with meticulous care in the official gazette. The report of events in the year 109 AD starts as follows: Xk(alendas) Iil(ias) imp. Nerva Traianus Caes. Aug. Germ(anicus)/Dacicus thermas suas dedicavit et publicavit./ VIII k(alendas) Iul(ias) aquam suo nomine tota urbe/ salientem dedicavit. ${ }^{21}$

The Latin passage references the dedication of the bath complex and the aqueduct that bore Trajan's name. This sheds light on the intimate relationship between the Traiana and the Baths of Trajan. It states the date of both of these structures' dedications, which fall within two days of each other, thereby linking the Traiana to the water supply in the public baths. This was also confirmed with an archaeological excavation in which eight inscribed lead pipes were discovered. The inscriptions ${ }^{22}$ left no doubt that the pipes were used for Trajan's Baths, that they had been laid by Emperor Trajan's authority, and that they were supplied with water from the Aqua Traiana. Recent chemical analysis of deposits found in these pipes support the theory that the water that once flowed through them originated in the lime-poor, volcanic regions of Lake Bracciano. ${ }^{23}$ This ties the aqueduct to the mills, Trajan's Bath complex, and also joined the network of aqueducts that supplied water throughout the entire city.

Archaeological evidence has revealed that the Aqua Traiana, once thought to have been one of Rome's most limited aqueducts as far as water supply, was one of the most extensive in the city. The craftsmanship and continuous repairs kept this aqueduct running until the line was

\footnotetext{
${ }^{21}$ Herbert Bloch, “Aqua Traiana” in American Journal of Archaeology vol. 48, no. 4 (Oct.-Dec., 1944$):$ pp. 339.

${ }^{22}$ The pipes read: Therm(ae) Traian(i), Imp(eratoris) Caes(aris) Merv(ae) Traiani Aug(usti) Germ(anici) Dacici sub cur(a) Hesychi Aug(usti) l(iberti) proc(uratoris), Themistus ser(vus) Alexandr(ianus) fec(it), Aq(ua) Tr(aiana). Taylor, Rabun, Public Needs and Private Pleasures, 211. The first part of the translation Therm(ae) Traian(i) indicate the pipes are going to Baths of Trajan; the second part Imp(eratoris) Caes(aris) Merv(ae) Traiani Aug(usti) Germ(anici) Dacici sub cur(a) Hesychi Aug(usti) l(iberti) proc(uratoris), Themistus ser(vus) Alexandr(ianus) fec(it), containing Emperor Trajan's full title indicate the imperial authority who laid the pipes; and the third part of the translation $A q($ ua) $\operatorname{Tr}$ (aiana) indicates the aqueduct that supplied the water.

${ }^{23}$ Günther Garbrecht, Die Wasserbewirtschaftung römischer Thermen: archäologische und hydrotechnische Untersuchungen; DFG-Forschungsvorhaben Ga 183/29 (Braunschweig: Leichtweiss-Inst., 1994), 151.
} 
cut during the Gothic invasion in 536-537 CE. After the Goths left, Belisarius, a general under the emperor Justinian, repaired the aqueduct to revive the water supply to the Transtiberium. An inscription found near the original power source confirms this. ${ }^{24}$ It was the last documented major repair to the Aqua Traiana, until Pope Paul V revitalized this aqueduct's path, and documentation of the Aqua Traiana was lost. It is logical to assume that after centuries of failed patchwork, proper upkeep, maintenance, and regular cleaning, the aqueduct fell into disrepair. As a result, the different areas of Rome it had once supplied with such a valuable resource, were cut off from easily accessible drinking water, and again relied on the aqueducts found on the eastern side of the Tiber as viable water sources.

The Aqua Traiana was not the only aqueduct that suffered from a lack of maintenance. Throughout the Middle Ages, Rome deteriorated and fell into shambles. The city had crumbled "column by column and brick by brick. By the middle of the fifteenth century, buildings were in ruins, streets were impassible, epidemics were inevitable, and wolves prowled outside the Vatican's walls." 25 Rome's once celebrated water infrastructure had almost completely vanished; only a few ruins remained-haunting echoes of its ancient splendor.

This changed when Pope Pius V built the Aqua Vergine from 1560 to1570 with remnants of the Aqua Virgo. For the first time in centuries, fresh, pure aqueduct water flowed again in Rome. The restoration of the aqueduct rejuvenated the residents of the city. The new water supply not only improved aspects of daily life, like sanitation, but this hydraulic technology allowed for rational urban planning which allowed for a citywide beautification in the

\footnotetext{
${ }^{24}$ Taylor, Public Needs and Private Pleasures, 208. For an argument against this see Ward-Perkins, J. B., From Classical Antiquity to the Middle Ages: Urban Public Building In Northern and Central Italy Ad 300-850 (Oxford [Oxfordshire]: Oxford University Press, 1984.) Perkins argues the Goths repaired the aqueduct before Belisarius seized Rome.

${ }^{25}$ Katherine Wentworth Rinne, The Waters of Rome: Aqueducts, Fountains, and the Birth of the Baroque City (1st ed. New Haven: Yale University Press, 2010), 6.
} 
construction of villas and gardens. ${ }^{26}$ The sixteenth and seventeenth century popes that succeed Pius V followed his example by restoring water to the city of Rome. These revitalized waterways not only served as a form of civic improvement and betterment of public life, but as a political link to the great emperors and papal power over the city of Rome. Pope Sixtus V, like Pope Pius V before him, used this rationale when he restored the remnants of the Aqua Marcia and Aqua Alexandrina (stitched together through construction), and renamed it the Aqua Felice from 1585 to 1587 . By the time these restored aqueducts were up and running, the majority of the city had regained access to fresh water. Pope Paul V's addition of the Aqua Paola was the last piece in the puzzle of Rome's water infrastructure.

However, the area of Transtiberium, henceforth referred to as Trastevere, was not reaping any of the benefits of this newly restored water system. This was the situation when Camillo Borghese, who took the name Paul V, was elected pope. Pope Paul V reigned for sixteen years, from 1605 to 1621 , and from the moment he was elected, he was ambitious about building projects in Rome. He wanted to leave his mark, architecturally, civically, and economically, on the great city and to rival, or even exceed, the achievements of his predecessor, Sixtus V. Henry Vollam Morton, a British journalist and pioneering travel writer wrote,

In the year of his election the Villa Borghese was founded, and in the course of his pontificate he enlarged the Vatican and the Quirinal; he built the Borghese Chapel in Santa Maria Maggiore; he altered the plans for the rebuilding of St. Peter's by lengthening the nave and adding the façade (and also putting his name above the portico); and he built a new aqueduct, the Aqua Paola, whose waters still display themselves in the piazza of St. Peter's. ${ }^{27}$

By the time he came to power, the west bank of the Tiber had little fresh water because the channels of the Aqua Traiana had been reduced to ruins. These have since been swept away by the Tiber's flow, erasing most evidence of this once powerful contributor to Rome's water

\footnotetext{
${ }^{26}$ Rinne, The Waters of Rome, 6.

${ }^{27}$ Morton and Carrieri, The Waters of Rome (London: Connoisseur; Joseph, 1966), 164.
} 
network. The residents of this area reverted back to using local springs and the water from the Tiber River as their main sources of water, which presented the same pollution problems as it had centuries before. Since the Cloaca Maxima was still flowing into the Tiber, the river and wells around were heavily polluted and not safe to consumption. Just as in ancient times, the east side of the river had multiple aqueducts that supplied the city to the western side of the Tiber with fresh water. Every time the "inhabitants of Trastevere crossed the Tiber they saw fountains of the Vergine and the Felice sparkling on the left bank, a display of good fortune which made their own medieval conditions hard to bear." 28 Faced with the same civic problem as Emperor Trajan in $103 \mathrm{CE}$, Pope Paul V elected to build an aqueduct, which would distribute water from the Janiculum Hill to the areas located on the western bank of the Tiber. By constructing the Aqua Paola, Pope Paul V, like his predecessors hoped to restore Rome to its former glory.

Even though the addition of a third aqueduct would drastically improve water supply, and by extension the living conditions in Trastevere, Janiculum Hill, and districts beyond the Tiber, Pope Paul V's principal concern was water distribution for the areas of the Vatican and the Borgo. Like his predecessors, Paul V wanted the Vatican's garden to have beautiful and magnificent fountains within their walls to exhibit his wealth. ${ }^{29}$ Also, the area of Borgo, located on the west bank of the Tiber, south of the Vatican and north of Trastevere, was heavily populated during the medieval and Renaissance periods. It, too, was not receiving a steady supply of water because of its location. Much like the area of Transtiberium was to Trajan's Baths, Trastevere and its majority of lower class residents were an afterthought to the more elite class of the Borgo, where "important cardinals and other churchmen... (including Cardinal

\footnotetext{
${ }^{28}$ Morton and Carrieri, The Waters of Rome, 164.

${ }^{29}$ Rinne, The Waters of Rome, 138.
} 
Scipione Borghese)[the pope's nephew]" were "clamoring for water."30 Since the water was to be supplied to the western edge of the city, it made logistical sense that the springs, streams, and rivulets that fed the aqueduct would also be located to the west of Rome. This plan was further simplified in engineering and planning requirements because the aqueduct no longer had to cross the Tiber, since, over the centuries, the Baths of Trajan were reduced to ruins.

This made the springs that once supplied the Aqua Traiana the obvious choice, and in 1607 Pope Paul V sent Cardinal Giovanni Evangelista Pallotta di Camerino and Monsignor Ottavio Tassone, the commendatore of the Banco Santo Spitito and financer of the project, to investigate the springs in this area. ${ }^{31}$ Among the streams examined, those that were part of the Aqua Flora streams, found on the northern and western slopes of the lake, showed the most promise. They had "nearly twice as much water as those supplying the Aqua Felice, and because they originated at a high elevation they had the potential to provide water that would rise as high as 'the cornice that stood above the columns of the cupola of Saint Peter's.",32 The potentially spectacular display in the fountains of the Vatican was something that was unequaled anywhere else in the city of Rome, and therefore very appealing to Pope Paul V.

He purchased the tributaries in 1607, and engineers immediately began working on the new channel that would supply the western side of Rome with water. It is important to note that Pope Paul V's new aqueduct did not actually use the existing ruins of the channel of the Aqua Traiana, but instead followed the path the aqueduct took south from Lake Bracciano. The route of the Aqua Traiana was useful because of the lack of topographic change; however, by the time the Aqua Paola was built, the Aqua Traiana had deteriorated to a point that the original channel was no longer functional. According to Christoph Heilmann, the Aqua Paola "represents a

\footnotetext{
${ }^{30}$ Rinne, The Waters of Rome, 138.

${ }^{31}$ Rinne, The Waters of Rome, 139.

${ }^{32}$ Rinne, The Waters of Rome, 139.
} 
restoration of Trajan's Aqueduct, but at the time it was well known that the antique remains were not those actually used to carry the water." 33 Even though the Aqua Paola did not reuse the complete structure, its proximity to the Aqua Traiana allowed the engineers to reuse some of the Aqua Traiana's masonry, which they broke up and implemented into the cement of the new Aqua Paola.

The Paola, like the Traiana before it, had segments of varying sizes, widths, and heights; however, unlike the Traiana, the work constructing the aqueduct was to be divided up between the towns along its pathway that used its water. An edito, or edict, was issued February 15, 1608, which explained in detail how this work was going to be organized. The masons were divided into four groups coinciding with the four major segments of the aqueduct. The first segment was from Rome to the "Casaletto [rural residence] del Signore Girolamo Mignanelli"; the second from Casaletto del Signore Girolamo Mignanelli to the "Quarto di Santo Savo passata la Storta" from the private property of Santo Savo, passing through the village of la Storta; the third from the Quarto to the town of Anguillara; and the fourth "fino alle Scaturighini delli fonti" from Anguillara to as far as the originating springs, which were located on the northern bank of Lake Bracciano. Each segment was then subdivided and assigned supervisors. The first segment had ten, the second segment had two, and the third and fourth segment each had fifteen. The segments were split according to the topographical terrain they covered. The supervisors and workers reflected the skills needed for the specific segments. Where the aqueduct needed to cross a valley, laborers skilled in arch construction would be assigned to that particular segment, sections that were subterranean would employ workers who specialized in carving out tunnels. Whenever possible, local masons, craftsman, and engineers were used to cut down on the cost of

\footnotetext{
${ }^{33}$ Christoph H. Heilmann, "Aqua Paola and the Urban Planning of Paul V Borghese" (The Burlington Magazine. 112 (811), 1970), 660.
} 
labor. ${ }^{34}$ Separating the aqueduct into segments and dividing the work amongst different groups of people ensured the aqueduct would be finished within an acceptable timeframe. ${ }^{35}$

Though the original reason for the new aqueduct was to supply the Vatican and the Borgo with water, Pope Paul V soon realized that it was crucial that the area of Trastevere be included in his urban plan as well. Supplying this area with water served several purposes. First, it brought fresh water to the area's growing population, and made the area more sanitary. Second, the potters and other artisans in the area who used the fresh water for their work would increase productivity and potentially improve their economic gain. Lastly, it provided fresh water to Ripa Grande, one of Rome's major ports. ${ }^{36}$ Supplying the port with fresh water provided Paul V with justification for transforming the area, further solidifying the mark he would leave on the city.

Even though Pope Paul V benefited economically from including Trastevere on the aqueduct line, in addition to supplying water to the Vatican, the aqueduct's benefit were perceived as falling "mainly to the Roman people, and for this reason and because of an ancient privilege of the Comune di Roma with regard to the water supply, it was only understandable that the Roman people should have to participate in the costs of the undertaking." ${ }^{, 37}$ Because the Aqua Paola helped Rome at large, Pope Paul V appealed to the Roman Council and insisted they pay half of the cost. Unfortunately for the citizens of Rome, the way the Roman Council made the majority of this money was to tax the public at a higher rate. So while Pope Paul V implemented his urban plan under the guise of the public good, having the residents of Rome pay for most of the construction, likely created some unrest.

\footnotetext{
${ }^{34}$ Rinne, The Waters of Rome, 140; Biblioteca Casanatense, "Editto sopra il appalti de lavori da farsi per la condotta dell'Aqua de Bracciano á Roma," 15 February 1608.

${ }^{35}$ While I have not found documentation as to how the Aqua Traiana was built, since the Aqua Traiana and the Aqua Paola both follow the same course through multiple towns. One can speculate that the Aqua Traiana's was built in a similar piecemeal fashion because of the segments varying heights, widths, materials, and construction styles.

${ }^{36}$ Rinne, The Waters of Rome, 139.

${ }^{37}$ Heilmann, "Aqua Paola and the Urban Planning of Paul V Borghese," 660.
} 
In an effort to more quickly make his mark, Pope Paul V began construction on his aqueduct before the plan was finalized. As a result, the construction of the aqueduct took just four years to complete. Out of the three existing aqueducts, the Aqua Paola had "the highest elevation and highest water pressure - had the widest distribution [...] it supplied the Vatican and Saint Peter's, the new grain mills on the Janiculum Hill, the low areas of the Borgo and Trastevere, and the left bank of the city, reaching those areas not fed by the Vergine and Felice. ${ }^{38}$ The Aqua Paola split into two separate branches once it arrived in Rome. One of the branches headed east toward the Vatican, its gardens, and the Borgo, while the other climbed up the Janiculum Hill and then descended into the area of Trastevere. (Figure 1.6) These water distribution plans were mapped out well in advance, making sure important families along the route received more than enough water for their villas and vineyards, before the aqueduct entered into the city to serve the private and public fountains there.

The sheer amount of water transported by the Aqua Paola ensured it would play a significant role in Rome's hydraulic infrastructure. By the time it was completed, Pope Paul V had achieved his ambitious goal of creating well-watered gardens for the cardinals and nobles who resided in the Borgo. The volume of water the aqueduct brought to Rome not only allowed the two hillsides of the Vatican and Janiculum to be lush and green, once again creating a living landscape around Rome, but also served the utilitarian function of incorporating the area of the Borgo, Trastevere, and the Jewish ghetto into the water distribution system. ${ }^{39}$ The importance of this aqueduct within the system is shown in the detail of Matteus Greuter's 1618 map of Rome. (Figure 1.7) In this map Greuter conceptualized Rome's water supply of aqueducts and rivers by depicting the three main aqueducts of the time - the Aqua Vergine, Aqua Felice, and Aqua

\footnotetext{
${ }^{38}$ Rinne, The Waters of Rome, 4.

${ }^{39}$ Rinne, The Waters of Rome, 154.
} 
Paola - as nymphs pouring their waters into a single large aqueduct, which is then joined by the Tiber, the Teverone (Aniene River), and the Marrana. All of the water is then poured out into a single river with Romulus and Remus suckling the she wolf. With this etching Greuter portrayed all the large-scale components that made up Rome's hydraulic infrastructure, while conveying their significance to the city's functionality.

At different points in history, the Aqua Traiana and the Aqua Paola played similar roles in supplying the city of Rome with water. At the time of their construction, while serving a very distinct political purpose, each was also vital in bringing an isolated area clean, usable water. This allowed the city to expand past its walls into areas that were previously uninhabited, with the promise of a steady supply of water. With this expansion came the need for new elaborate urban plans that highlighted both the aqueduct and its components. Both Emperor Trajan and Pope Paul V used their respective aqueducts as justification to reinvent old sections of Rome, ensuring their everlasting mark on the city. 


\section{CHAPTER 2 \\ IL FONTANONE}

The introduction of the Aqua Paola's water supply to the area west of the Tiber was enough to initiate a large-scale transformation in Trastevere. During the Middle Ages, disease, famine, war, and flooding took its toll on the citizens of Rome and on their beloved city. The deteriorated shell of the city served as a reminder of Rome's previous grandeur. In the hopes of re-establishing this splendor, Pope Paul V constructed the Aqua Paola creating a steady supply of clean, potable water that would help restore life to Trastevere. The first part of Trastevere's revitalization and of Pope Paul V's overall urban plan for the area involved building a large fountain where the Aqua Paola arrived on the Janiculum Hill. The city of Rome has a longstanding tradition of placing a large ornamental public fountain along the line of the aqueduct, which is designed specifically for the display of that particular aqueduct's waters. This being said, the mostra fountain of the Acqua Paola, is unique not only in the construction materials used, but it was also an integral part of Pope Paul V's plan to revitalize Trastevere.

This mostra fountain was known as Il Fontanone, or Big Fountain. (Figure 2.1) What makes a fountain a mostra is "not essentially its size or splendor, but its specific designation as the fountain that is a public memorial to the whole achievement of the aqueduct." ${ }^{, 40}$ Often, these fountains are highly ornamented and include an inscription that celebrates the architect of the fountain as well as the benefits of the aqueduct's water in reference to the city of Rome. Il Fontanone was no exception. The fountain acted as an extravagant advertisement for Pope Paul V's accomplishment of bringing water to the west side of Rome.

\footnotetext{
${ }^{40}$ Peter J. Archer "Display Fountains ("Muster") and the Aqueducts of Ancient Rome." Phoenix vol. 47, no. 4 (Winter, 1993): 339.
} 
By the time of Il Fontanone's completion, it was the largest ornamental fountain found in Rome. In fact nothing surpassed its monumental size until 1762, when the Trevi Fountain was completed. $^{41}$ The inscription celebrating the patron, Pope Paul V, and the benefits of the water for the city of Rome is still seen today on the attic of the fountain. ${ }^{42}$ (Figure 1.2) However, as discussed in Chapter 1, it cites the wrong ancient aqueduct as the source of the Aqua Paola. Pope Paul V used this fountain as the focal point of his ambitious large-scale urban plan for the western bank of the Tiber River. Before looking into his plan for the city of Rome, it is important to analyze the fountain and expand upon the historical importance of its design.

Both the aqueduct and monuments along its path were expensive undertakings and, therefore, required funds to be raised beforehand. Like the Aqua Paola, an aqueduct built primarily for civic use, Il Fontanone was a public fountain and therefore was partially paid for by the public. The most productive way to do this was initiating a tax on wine that the public, the tavern owners, and the innkeepers had to pay. Pope Paul V, issued an avviso, or notice, on August 22, 1607 that explained the taxes on the wine went to pay for the water conduit. ${ }^{43}$ The majority of the people in Rome did not understand the need for another new aqueduct. As far as anyone on the eastern bank of the Tiber was concerned, the Aqua Vergine and the Aqua Felice were bringing more than enough water for the people of Rome. In their minds, this grand fountain merely acted as a spectacular advertisement for Pope Paul V's accomplishment of bringing water to Rome, while the taxes he imposed on the public made its financing possible. However, the people on the western edge of the river who were getting very little clean water had an entirely different perspective. While they might not have liked to pay the tax, they could

\footnotetext{
${ }^{41}$ Rinne, The Waters of Rome, 146.

${ }^{42}$ See Chapter 1 , footnote 8 for original inscription and translation.

${ }^{43}$ The notice reads, "Si sentira un gran stillare a far pagar il vino per condurre 1'Aqua," The tax on the wine will be used to pay for [the Aqua Paola] conduit. D'Onofrio, Cesare, and Max Dellacher, Le Fontane Di Roma: Con Documenti E Disegni Inediti. $2^{\text {nd }}$ ed. (Roma: Staderini, 1962), 145.
} 
not deny that as residents of the western bank, they were in need of a substantial amount of usable water for both public and private uses. The Aqua Paola and its grand fountain ensured this area received the volume of water it needed.

The idea to create this monumental fountain began in 1607 when the planning stages for the aqueduct were underway. Designed by Giovanni Fontana (1540-1614) and Flaminio Ponzio (1560-1613), Il Fontanone was the first major fountain on the west bank of the Tiber. The tract of land on which Pope Paul V chose to build his fountain was atop the Janiculum Hill, where it dominated the sightlines of the city of Rome. Because of its size, the fountain also served as a focal point in the surrounding landscape and urban area. It existed as a landmark that was easily seen throughout the city and, therefore, Pope Paul V used the fountain as the center of his urban development plan. Ironically, during this time the Janiculum was a relatively unpopulated, rural area that contained orchards, vineyards, and a handful of palaces and monasteries. ${ }^{44}$ Because the scenic hillside was unpopulated, its visibility, combined with its ability to distribute water to the entire western side of the city, made Il Fontanone historically and socially significant.

Il Fontanone's significance is depicted in Greuter's map of Rome (Figure 2.2) produced in 1618. This map was made four years after the fountain's completion and although Il Fontanone is not labeled, its structure is documented on the Janiculum hillside. The fountain's importance becomes more apparent in Francesco de Paoli’s 1623 map of Rome (Figure 2.3), where Il Fontanone, is both depicted and labeled. ${ }^{45}$ Paoli's map creates a clear picture of the area surrounding the fountain, showing a rural landscape, supporting the claim of the fountain's visibility from Trastevere. Not only did it supply the largest area of Rome, but it also provided multiple classes of people, the working class area of Trastevere and also the well-to-do residents

\footnotetext{
${ }^{44}$ Rinne, The Waters of Rome, 138.

${ }^{45}$ Il Fontanone is also referred to as the Aqua Paola, as it is labeled in Paoli's map. For clarity purposes this project only refers to it as Il Fontanone, even though it was known by both names.
} 
of the Borgo and the Vatican with clean water. No other aqueduct at the time could measure up to that task.

The importance of the aqueduct and, by extension, Pope Paul V had to be expressed in the architecture of the fountain. Today, as in ancient times, Il Fontanone sits atop the Janiculum overlooking the sprawling urban city of Rome. The fountain is divided into five bays, articulated by six pink Aswan ionic columns on either side. The color visually breaks up the single story monumental façade. The three middle bays contain central arches that are twice the width of the remaining two flanking bays. Sitting atop the three middle arches is a monumental attic, which contains the commemorative inscription, above which sits the papal seal flanked by two angels. The first traces of the water running through the fountain begin below the column base in each bay, where a cascading stream emerges and falls into the large semi-circular basin. The constant flow of five streams of water into an already filled basin, creates a continuous sound as well as a rippling effect on the otherwise calm surface. When viewing the fountain from the front, it becomes apparent that there is more to it than a magnificent façade. Even though the two smaller flanking bays are completely closed off, the three middle bays each contain an opening, which serves as an introduction to the loggia and garden, undoubtedly watered by the Aqua Paola located behind its façade.

Pope Paul V wanted this fountain to overshadow any other previous works, to be unparalleled in its magnitude and grandeur. The five-bay fountains was based loosely the threebay fountain of the Aqua Felice, also called the Fountain of Moses, which was designed by Domenico Fontana from 1585-1588. (Figure 2.4) The Fountain of Moses is divided into three closed bays, each articulated by an ionic column on either side of the space, four in total, visually breaking up the single story monumental façade. Resting atop the three arches is a monumental 
attic, with a commemorative inscription, above which sits the papal seal being held up by two angels. These fountains even display their water in a similar fashion. The Fountain of Moses uses three cascading streams, one per bay, that fall into their own separate basin. However alike these fountain visually appear, there are some distinct difference that set Il Fontanone apart from any other fountain designed during this time period. Like the aqueduct that it accompanies, the fountain is larger and more extravagant then anything that was designed previously in the city. Also, rather than using religious subjects to convey a spiritual message like the Aqua Felice, an oversize sculpture of Moses stands in the middle bay, connecting the fountain's patron, Pope Sixtus V, to Moses who once brought water to the Sinai Desert. ${ }^{46}$ The grandiose architectural form and scale of Il Fontanone expresses the importance of Pope Paul V and the entire Borghese family to the city of Rome. All aspects of the fountain, from its size, location, and materials are a symbol of the wealth, power, and influence of Pope Paul V and by extension his entire family within the city of Rome.

The original conception of Il Fontanone is shown clearly in two prints made by Giovanni Battista Falda (1643-1678), an Italian architect, engraver, and artist. (Figure 2.5) The architecture of the fountain beautifully harmonizes all aspects - the integration of architecture, sculpture, inscription, and water-within its design. The fountain, designed by Giovanni Fontana, presented a new architectural idea of a three-dimensional arcade focused on the perception of the individual viewer. Instead of the closed arcade, as found behind the Fountain of Moses, the openings found in the three middle bays of the of Il Fontanone give the viewer a brief glimpse of what lies behind its monumental façade. The middle bay contains the largest aperture, providing the best view of the arcade and garden behind; however, the two flanking

\footnotetext{
${ }^{46}$ Rinne, The Waters of Rome, 128.
} 
bays contain the same size cut out. ${ }^{47}$ This was done intentionally so as not to draw the viewer's attention to the middle archway, but instead to spread the central focus over all three of the bays. This makes the visitor conscious "not only of the fountain itself, but also of its relations to the loggia and garden beyond."48 Assessment of the garden draws focus away from the architectural structure of the fountain, and highlights the role of water within the design. Once the viewer realizes this connection, the functionality of the fountain becomes clear. The design is not strictly decorative, but was also built around the pressure, flow, and volume of the water it was bringing to Rome. Il Fontanone's size and the continuous flow of water through all five bays serves as a reminder to the viewer of the volume of water coursing through this fountain. Through its visually striking water features, appearing in both streams and a large pool, this fountain symbolically elevates the importance of water in Rome over architectural prowess. Further emphasizing this idea are the "five vigorous streams rushing [from each of the five bays] into small marble basins giving [the public] direct access to the cascades." "49 This fresh clean water was a drastic change from the past when local residents were gathering water from dirty springs, or even worse, the water of the Tiber. Since there was now a fountain with potable water located in Trastevere, the residents were supplied with a seemingly endless supply of fresh water. Not only did the fountain succeed in the utilitarian purpose of supplying fresh water, but it also achieved aesthetic beauty, in the simplicity of its grandiose architectural form. Sitting atop the Janiculum, in the midst of orchards and vineyards, it was an ever present symbol to the city of the extensive water infrastructure of Rome.

\footnotetext{
${ }^{47}$ Heilmann, "Acqua Paola and the Urban Planning of Paul V Borghese," 659.

${ }^{48}$ Heilmann, "Acqua Paola and the Urban Planning of Paul V Borghese," 659.

${ }^{49}$ Marilyn F Symmes, Kenneth A Breisch, and Stephen Astley, Fountains: Splash and Spectacle: Water and Design From the Renaissance to the Present (New York: Rizzoli in association with Cooper-Hewitt, National Design Museum, Smithsonian Institution, 1998), 37.
} 
As significant as the elegant marble fountain built by Pope Paul V was, it was also unique for the time period because it was made entirely of spoliated marble. Spolia was the reuse of older building materials in new structures or monuments. While this was not new during the Renaissance, it was unusual to have a monument made completely out of reused marble.

Material reuse was mainly used as a cost saving measure, but in this case it served as a visual and symbolic connection between Pope Paul V and the ancient Roman emperors. The marble for Il Fontanone was taken from a variety of buildings in the Roman Forum, the Temple of Minerva and the Forum of Nerva. ${ }^{50}$ The reuse of ancient marble from multiple sources led to a lack of uniformity in the façade of the fountain. Pentelic, Carrara, and Proconnesian are each different shades of white marble, and therefore give the fountain a somewhat dappled appearance. Giovanni Fontana utilized spolia to design ascents of colored marble from the old Constantian Basilica of St. Peter's. The four central columns of red Aswan granite came from the basilica's quadriportico and the columns of grey granite hail from the basilica's façade. ${ }^{51}$ This association combined with the monumentality of Il Fontanone left no question as to Pope Paul V's political power in the city of Rome.

While aesthetically the fountain was regal and magnificent, there were major mechanical obstacles to overcome. The fountain was originally engineered so each of the five separate bays had its own cascading stream of water that emptied into a separate basin at ground level. While this paints a calm and tranquil picture, the first tests of the fountain were anything but that. Giovanni Fontana, who was familiar with this style of grandiose architecture, applied what he had learned working with his brother on the Aqua Felice mostra fountain found on the Quirinal Hill. However, while the large elevation change between the Quirinal and Janiculum Hills

\footnotetext{
50 "Il restaure della mostra dell'Aqua paola al gianicolo," Comune di Roma, 2004.

51 "Il restaure della mostra dell'Aqua paola al gianicolo," Comune di Roma, 2004.
} 
created an opportunity for larger, higher, and more exuberant displays of water, Giovanni Fontana and Ponzio failed to account for some of the engineering problems that resulted from designing a similar fountain on different hill.

The Janiculum is a much steeper hill "falling away precipitously to the east just in front of Il Fontanone, which meant that greater stress was exerted on the distribution pipes."52 Because of this additional stress and unaccounted stress, during the first test run in late 1611, the water arrived with such force that it smashed one of the fountain's marble basins. ${ }^{53}$ This would have been less of a problem if the water could have been turned off immediately, but because the diversion point where the aqueduct splits to go to the Vatican was quite a distance away, the result was that the water continued to run through the broken basin into the earth directly beneath for five days. This gathering water eventually broke through a wall in the lower part of Trastevere and flooded the area around San Cosimato. ${ }^{54}$ This continued for a full seven months before the necessary repairs were made to the fountain and the velocity of the water arriving at the Fontanone was decreased to a reasonable rate. ${ }^{55}$ While the water of the Aqua Paola was a vital resource, the damage to the walls and structures located at the bottom of the Janiculum, caused by the inability to harness its flow, likely created tension between the residents and the fountain's engineers. It also created unforeseen economic costs, not only because engineers had to figure out how to control the fountain's pressure, but also because damages caused by overflowing water had to be rebuilt.

These quick fix provided by the engineers proved temporary, and only a few short years later, during the reign of Pope Urban VIII, the conduits broke again and caused a landslide along

\footnotetext{
${ }^{52}$ Rinne, The Waters of Rome, 146.

${ }^{53}$ Rinne, The Waters of Rome, 146; Johannes Albertius Franciscus Orbaan, La Roma di Paolo V negli Avvisi (Rome: Biblioteca Vallicelliana, 1920), 178-179.

${ }^{54}$ Rinne, The Waters of Rome, 146.

${ }^{55}$ Rinne, The Waters of Rome, 146.
} 
portions of the Janiculum's slope, flooding many structures nearby. This was an economically costly event. In hopes of fixing the flooding problem, the fountain was redesigned by Carlo Fontana, the original designer's brother. Christoph Heilmann states, "the opening of this central axis and also the wide semi-circular basin are the work of Fontana, who in 1672 was commissioned to improve the water supply, and in consequence, altered the façade in $1690 .{ }^{56}$ (Figure 2.6) Carlo Fontana replaced the five separate basins with a single large basin. He hoped this change would control the flooding because it would be able to hold a larger volume of water. This proved to be inadequate and the problem of flooding continued.

It was not until the end of the seventeenth century, nearly fifty years after the death of Pope Paul V, that the power of the Aqua Paola was properly harnessed by the addition of an intermediate holding tank and the construction of new grain mills along the ridge of the Janiculum. ${ }^{57}$ Though mills had not been active on the hillside since antiquity, they had since relocated to the bustling industrial district found by the Ripa Grande. The restoration of this industry on the hill would help with the fickleness of the Aqua Paola. The new mills, like their ancient counterparts, used a significant volume of water, therefore reducing the supply of water that Il Fontanone had to retain. Rinne explains, "Each new mill was designed to reuse the water from the mill above it, thus slowing down the water and lowering the pressure so that the pipes would not burst." ${ }^{58}$ This economically transformed an area of the Janiculum back to its industrial roots. Though the mills were constructed after Pope Paul V's death, their proximity to the fountain connected them back to his achievement of supplying the water through the construction of his aqueduct.

\footnotetext{
${ }^{56}$ Heilmann, "Acqua Paola and the Urban Planning of Paul V Borghese," 656.

${ }^{57}$ Rinne, The Waters of Rome, 146.

${ }^{58}$ Rinne, The Waters of Rome, 148; Archivio di Stato di Roma, Presidenza degli acquedotti urbani, 336/114: 79v, 8 OV- 8IR, and $92 \mathrm{~V}-93 \mathrm{R}$
} 
The design and the mills finally made the fountain the focal point of Pope Paul V's urban plan. Il Fontanone's construction signifies the beginning of the urban transformation that took place in Trastevere and the Janiculum. Its dominating appearance on the landscape from its dedication in 1612 into the early eighteenth century was unprecedented in the history of fountains in Rome. Even though the encroachments of more recent urban development weakened the full impression of this, it is still possible to envision its significant influence on the water infrastructure found on the west bank of the Tiber. Author Henry Morton encapsulates the fountain's significance when he says,

Mounted high upon the Janiculum, with the whole of Rome' beneath it, this fountain stands magnificently situated amid the last surviving tranquility of the nineteenth century. It is off the tourist run so that the thousands who linger around Trevi are unaware of its existence, while many who follow the antiquarian route laid down in the eighteenth century generally lack the time to go there. I think it is one of the most rewarding sights in Rome. I have found that it often offers the unusual experience in these days of being alone with a famous monument. I have also found it stimulating... to find an arch that is still alive: that announces with a flourish the triumphant arrival of an aqueduct's water in Rome. $^{59}$

Though Il Fontanone originally had some engineering problems, once these were overcome, the fountain outshone any fountain built before in Rome. Its dedication marked the first transformations seen on the Janiculum since antiquity. Not only was the spatial change apparent through Il Fontanone's monumental architecture and its use of spoliated materials, but the fountain was also symbolic of the political power Pope Paul V held in Rome during his papacy. It was the crown jewel of Pope Paul V's entire plan for the Vatican gardens and the Borgo, and it catalyzed the revitalization of the entire area of Trastevere.

\footnotetext{
${ }^{59}$ Morton and Carrieri, The Waters of Rome, 164.
} 


\section{CHAPTER 3}

\section{URBANISM IN SEVENTEENTH-CENTURY ROME}

There is no question that the Aqua Paola, Il Fontanone, and Pope Paul V have earned their place in Rome's history. Pope Paul V's foresight in building the aqueduct and fountain allowed the city of Rome to expand across the river, while remaining a part of the already extensive water system. Additionally, Pope Paul V's ambitions stretched further than simply adding to the hydraulic network; he wanted the fountain to be a prominent structure, a visible beacon that could be recognized throughout the city, especially in Trastevere, an area that was rejuvenated because of the addition of a constant supply of fresh water. For him, the construction of Il Fontanone was only the beginning. This chapter will demonstrate how the Aqua Paola and its fountain played a pivotal role in the development of other urbanistic achievements in early seventeenth-century Rome.

The Aqua Paola's position is one of both historic and social importance. This aqueduct had significant influence in town planning, even before it was incorporated into the water distribution system of Rome. A plan of the Aqua Paola's distribution system (Figure 3.1 ) ${ }^{60}$ first published by Heilmann in the article "Acqua Paola and the Urban Planning of Paul V Borghese," begins to unravel the relationship between the subterranean distribution of the fountain and its influence on the layout of the roadways. This plan illustrates the area between the Janiculum Hill and the Ponte Sisto, a footbridge built by Pope Sixtus IV (1414-1484) in Trastevere that was used as a major crossing for the Tiber. Il Fontanone is noted by a depiction of the fountain labeled "facciata della mostra dell'acqua Pauola" (the façade of the mostra of the Aqua Paola)

\footnotetext{
${ }^{60}$ Heilmann states, the dating of the plan to the early seventeenth century is based on the type of paper it is drawn on. The project is also dated as one that dates from the time of Paul V.
} 
found at the right side of the drawing. Below the fountain, the city wall is depicted by a heavy lineweight and the pipeline, represented by a thinner line weight, runs alongside it down the hill into Trastevere then along the Aurelian Wall to the Porta Settimiana, one of the gates found in the wall. (Refer to Figure 3.1) From there it heads to the lowest part of Trastevere, Piazza Ponte Sisto, where it divides into "eight individual siphons made of lead laid under the [road] bed of the Ponte Sisto." ${ }^{, 61}$ The siphons are clustered in groups of four, each group occupying a channel on either side of the road. This separation and the use of multiple smaller pipes are useful for a number of reasons. One, it is easier to control the pressure of the water with multiple pipes; two, a redundancy is useful to provide a backup system during pipe failure or bursting; and three, repairs and maintenance can be performed more efficiently with two channels. Multiple pipes allow an adequate supply of water to reach a majority of the target area at all times.

This plan, seen in Figure 3.1, also indicates the path the pipeline takes underneath the street infrastructure. Of particular interest, the axis that the line cuts through is the exact layout of the modern roads. ${ }^{62}$ In the seventeenth century, road construction in the city of Rome had a rational construction sequence based around the water infrastructure. This sequence is as follows: "identifying and purchasing obstructing properties, clearing roadways, surveying routes, digging trenches, and finally leveling and paving the roadbed." ${ }^{63}$ The pavement materials used by engineers at the time were very specific pavers known as sampietrini. (Figure 3.2) These small square cut stones were regularly faceted so that lateral support was provided to offset the weight of carriages, carts, and horses. In addition to keeping the street structurally sound, these pavers made maintenance of the water infrastructure less invasive. If a pipe burst under the street, the affected area could be taken apart piece by piece, the broken component replaced, and

\footnotetext{
${ }^{61}$ Rinne, The Waters of Rome, 150.

${ }^{62}$ Heilmann, "Acqua Paola and the Urban Planning of Paul V Borghese," 660.

${ }^{63}$ Rinne, The Waters of Rome, 150.
} 
the road repaired. This process ensured that the Aqua Paola remained an important water source in Rome adaptable to the city's growth and change.

To further the importance of the Aqua Paola and Il Fontanone, Pope Paul V issued an official report discussing his desire for a new roadway in Trastevere that highlighted the importance of the Aqua Paola. On June 26, 1611, an official report was issued which discussed the pope's desire to open a roadway from the Ponte Sisto to the terminating segment of the Aqua Paola. ${ }^{64}$ According to Heilmann "a great street, which was planned to lead from Ponte Sisto towards this dominating monument, would have been an exceptional ornament for [the area of] Trastevere." ${ }^{65}$ This road, which was to connect Trastevere directly to the top of the Janiculum, turned out to be impossible because the eastern topography of the hill was too steep for a road. Even though this street was never constructed, it is possible to imagine that a road leading straight up the Janiculum to the Fontanone would have created a distinct axis through the city that would draw public attention to the monumental construction. The road "would have implied not only the movement of the observer's eye, but the invitation to the observer to become involved in the project, ${ }^{, 66}$ drawing attention to the importance of the fountain as well as the aqueduct that supplied it.

Despite this unfinished project, some construction did take place, which also emphasized the pope's desire to draw attention to Il Fontanone. One report mentions two streets that he

\footnotetext{
64 "una strada dritta che da Ponte Sisto vadi a battere alla fontana principale; el per abbellimento della cittá e maggior commodimento de forastieri si pensa d'apri e far alcune alter strade nove tanto dentro l'habitato come fuori." A decision was made by [Pope Paul V] to design a straight road from Ponte Sisto to the principle fountain [Il Fontanone], to beautify the city for new people by creating new open roads that alter the area both inside and out. Cf. Orbann, op. cit. p. 191, avviso $25^{\text {th }}$ June 1611.

${ }^{65}$ Heilmann, "Acqua Paola and the Urban Planning of Paul V Borghese," 661; The report reads "Dum illustrandae parti Transtyberinae incumbitur, aliae aperturae duae viarum luxatae sunt, ad aquam in summitatem Montis Janiculi conductam a Pailo conspiciedam... Hace verius dici potest viae, grandis pars quam a Ponte Sixti ad conspectum praeclarissimi, ingentisque Fontis, patescere destinatum fuerat." The beginning of this great street, which was planned to lead from Ponte Sisto towards this dominating monument, [Il Fontanone] would have been an exceptional ornament to the area of Trastevere.

${ }^{66}$ Heilmann, "Acqua Paola and the Urban Planning of Paul V Borghese," 661.
} 
enlarged at several points leading up to the Aqua Paola, one of which stills exists today as Via Garibaldi. ${ }^{67}$ Widening the roads allowed more of the fountain to be visible, which clearly displayed its monumental architecture and unique design. Some fountains of the era were close in size to Il Fontanone, however, many of them were incorporated into an adjacent building, making them structurally interdependent. Il Fontanone was structurally independent, which was rare for a fountain of its size.

Before the aqueduct supplied water to this region, there was not enough water to support the public needs of the population, let alone the construction of monumental fountains. As a result, Trastevere continued to live in underdeveloped conditions, both socially and architecturally when compared with the rest of the Rome. The Middle Ages were difficult for the city of Rome, particularly in Trastevere. Disease, in the form of the bubonic plague, typhus, dysentery, and malaria, overtook the city, and the population who did not have significant roots in Rome, simply left. Famine and war also contributed to the city's decrease in population. While the whole city was suffering, Trastevere also had to deal with the regular flooding of the Tiber. During this time there was no embankment of the river that could serve as flood control: "Within a few hours whole quarters of [Trastevere] could be flooded to a depth of three of four meters, filled with stinking mud, and exposed to the danger of typhoid and other infections." 68 Adding to the unsanitary conditions of the area, the Aqua Traiana, which had once brought clean, fresh, potable water to Trastevere, had fallen into disrepair over centuries of neglect, so there was no usable water source left on the west side of the Tiber. By 1607, the living conditions on the west bank of the Tiber become intolerable and Pope Paul V decided to build the Aqua Paola,

\footnotetext{
${ }^{67}$ Heilmann, "Acqua Paola and the Urban Planning of Paul V Borghese," 661.

${ }^{68}$ Peter Partner, Renaissance Rome, 1500-1559: A Portrait of a Society, (Berkeley: University of California Press, 1979) 81.
} 
with his overriding concern being for the Vatican and the Borgo. ${ }^{69}$

The construction of the Aqua Paola and the region's subsequent ready supply of water meant Pope Paul V's urban ambitions would come to fruition in Trastevere. It was during his pontificate that once again Trastevere grew to be accepted as a hospitable area. One of his first projects was to build a street creating a dominating axis around which urban forms were constructed. Planning this road as a main thoroughfare allowed Pope Paul to control the built environment using Il Fontanone as the focal point for his urban design. Anything built that obscured the view of this monumental fountain was counterproductive to his plan. The street that was built would become known as Via San Francesco a Ripa.

Originally, this street was intended to link the newly enlarged Piazza San Francesco a Ripa to the prolongation of the Via Lungara. This would have made a single thoroughfare that connected Trastevere with both the Borgo and the Vatican. It would have crossed the axis of Ponte Sisto and the Aqua Paola at almost a perpendicularly angle, laying down the foundation for a typical grid-like pattern of streets. A network such as this would have undoubtedly changed the urban fabric of Trastevere, which is today known for its small, narrow, and winding streets. Although construction ceased in 1611 after only the first section from San Francesco a Ripa to San Callisto was completed ${ }^{70}$ Pope Paul V did provide a steady supply of water to the region and set in motion the rapid urban transformation of Trastevere. Upon study of the maps of Trastevere from before and after the construction of the Aqua Paola and Il Fontanone, this change was not necessarily found in the built environment because of the area's established urban fabric, but instead a significant social transformation. (Figure 3.3 and Figure 3.4)

\footnotetext{
${ }^{69}$ Rinne, The Waters of Rome, 138.

${ }^{70}$ Heilmann, "Acqua Paola and the Urban Planning of Paul V Borghese," 661; An avviso from the $15^{\text {th }}$ of June 1611 (cf. Orbaan, op. cit., p.191) speaks about the new axis being completed from San Francesco a Ripa to San Callisto and mentions a couple of houses that were going to be demolished in order for prolonging the street to Santa Maria in Trastevere.
} 
This change took many forms as Trastevere was integrated into the Roman hydraulic network. The Aqua Paola and its water lured a new population over the banks of the Tiber. ${ }^{71}$ First, it allowed for more industry to be based in and around Trastevere. People that used water in their trade, such as artisans and potters, could now move closer to the main port in Rome, the Ripa Grande. This meant the rebirth of a larger more populated industrial section closer to the river. Second, the area's population grew because of the influx of the industrial population and the increase in potable water. Previously, Trastevere's residents had the misfortune of using the Tiber for everyday water because they had no other convenient supply. Third, bringing fresh water to the port provided Pope Paul V with justification in further implementing his urban plan for the area. He constructed new streets which made the port more easily accessible as well as "commission[ing] a road from the Piazza de Santa Maria in Trastevere to the port that created development sites along it for new institutional, industrial, and residential uses."72 The placement of this new roadway, just like his decision to move the port to Ripa Grande was deliberate. He slowly turned Trastevere into a more commercialized area, a calculated move to boost Rome's economy.

As discussed in Chapter 1, Pope Paul V intentionally moved the port Ripa Grande in order to revitalize the area of Trastevere. As Heilmann states, "The new position of the port had not only excellent connections to the Vatican, but also led by way of the Ponte Sisto to the commercial district."73 Ripa Grande, which was situated directly behind the church of San Francesca a Ripa, was now in a location that provided economic justification for Pope Paul V's road construction. To execute his plan and make way for this new expansion, structures were torn down and Trastevere was reshaped in Pope Paul V's vision. To express their gratitude for

\footnotetext{
${ }^{71}$ Taylor, Public Needs and Private Pleasures, 247-248.

72 Rinne, The Waters of Rome, 139.

${ }^{73}$ Heilmann, "Acqua Paola and the Urban Planning of Paul V Borghese," 661.
} 
the success of Paul V's urban planning, the people decorated the façade of San Francesco a Ripa with a large commemorative tablet and inscription naming Pope Paul V and his urbanistic achievements. $^{74}$ All of his plans, specifically street construction, had a clear sightline to the Janiculum Hill and Il Fontanone atop it. This served as a daily reminder to the residents of Trastevere that Pope Paul V was solely responsible for their area's revitalization.

Pope Paul V not only helped rebuild the area of Trastevere, but also other areas along the edge of the Tiber. For example, when he moved the port slightly down the Tiber from the area of Ripetta — found in the Campo Marzo — to Trastevere, he had taken away a significant component of that landscape, and Ripetta suffered a decrease in population. Pope Paul V saw this as an opportunity to re-situate the Via Scrofa, the prolongation of Via Ripetta, and the main street used for the port, into his urban plan. The street was straightened and widened by the demolition of a few residential buildings, warehouses, and platforms. Its proximity to the new port proved to be the perfect location for his Papal family palace. ${ }^{75}$ The palace immediately made this area of Campo Marzo desirable for Roman residents. The area went from an unsavory lower-class neighborhood dominated by residents that worked at the docks to a higher class of nobility who wanted to own a residence in close proximity to the pope, creating a new neighborhood of a mobile upper urban class became a reality. ${ }^{76}$ People were moving not only to elevate their social status, with their proximity to the Papal family, but many of them were eager to escape from the overcrowded conditions of the east bank.

While Pope Paul V's ambitions in urban development mainly revolved around the layout of roads, he also wanted to transform the city's urban aesthetic. Although he had already achieved this with the monumental architecture of Il Fontanone, he also intended to display the

\footnotetext{
${ }^{74}$ Heilmann, "Acqua Paola and the Urban Planning of Paul V Borghese," 661.

${ }^{75}$ Heilmann, "Acqua Paola and the Urban Planning of Paul V Borghese," 662.

${ }^{76}$ Taylor, Public Needs and Private Pleasures, 248.
} 
water system he had restored all around its distribution area. This meant designing smaller ornamental public fountains that were to be scattered around the Aqua Paola's network. Since there were two different branches splitting off of the main aqueduct, one headed toward the Vatican and the other to Trastevere, there was a wide area in which Pope Paul V could build fountains that still connected to the Aqua Paola network.

After the mostra fountain on the Janiculum, Pope Paul V concentrated on a revitalization of the Vatican Gardens. Multiple years without an adequate water supply deteriorated the effects of the fountains in the garden, which visually took its toll. With nearly a third of the Aqua Paola's capacity being diverted to the Vatican, it was now possible for Pope Paul V to "create the kind of well-watered papal garden that had been envisioned by earlier popes... the new fountains graced vistas, created a restful and enticing environment for hot summer days, and impressed visitors from around the world." 77 These fountains were highly praised, and the beauty of the now flourishing and lush gardens soon became a central subject in literature, poetry, and paintings. The gardens were held in such high esteem that they contained their own mostra fountain, known as the Scoglio Fountain. (Figure 3.5) This was not only beautifully ornamented as it recalled a natural grotto, which was fitting for a monumental garden fountain at the time, but also served as a small distribution center for the area of the Vatican. ${ }^{78}$ Just as the Fontanone distributed water around the Janiculum Hill and in Trastevere, the Scoglio Fountain was fitted with lead conduits that divided and dispersed the water across the Vatican, Piazza San Paola, and the Borgo. This was an economic decision because the Scoglio fountain was located closer to these areas than Il Fontanone and was perfectly capable of supplying the Vatican and the Borgo with more than enough water.

\footnotetext{
${ }^{77}$ Rinne, The Waters of Rome, 141.

${ }^{78}$ Rinne, The Waters of Rome, 141.
} 
Soon after this fountain was constructed, Pope Paul V began building more fountains in and around the gardens. When he first undertook the task of building a new aqueduct, he was uncertain of the amount of water and power it would provide. Both the Aqua Vergine and Aqua Felice were not known for the sheer volume of water they supplied, like the Aqua Paola, but instead for their potability. On the other hand, the Aqua Paola and its engineered gravitational system was designed in a way that created more than enough volume and pressure to satisfy any fountain design. In fact, even after building the mostra and multiple other fountains, there was still enough water left to enable Pope Paul V to restore the garden's Belvedere fountain, which had previously been decommissioned because of a lack of water. He not only resurrected the fountain, but also installed a more exuberant water display than what had formerly existed. ${ }^{79}$ The architecture, number, and grandeur of these fountains within the Vatican along with the revitalization of the gardens ensured Pope Paul V would be remembered for his gift to Rome for centuries to come.

While this fountain's size and extravagance politically empowered Pope Paul V, the Scoglio fountain also served the function of a distribution center for the water on the Vatican branch of the Aqua Paola. Not only did it have pipes leading to the other fountains within the Vatican gardens, but the fountain's distribution reached as far as Piazza San Pietro, to supply the ornamental and drinking fountains found there. It also supplied the area of the Borgo and a multitude of places around the Vatican, from private family's palazzos to the Hospital of San Spirito. ${ }^{80}$ Since the Aqua Paola had two separate branches, including a distribution fountain on each of these was crucial because it allotted for the engineers to use these fountains as points along the line in which pressure, volume, and distribution could be easily monitored and repaired

\footnotetext{
${ }^{79}$ Rinne, The Waters of Rome, 141.

${ }^{80}$ Rinne, The Waters of Rome, 142.
} 
if a problem arose.

Through a number of these fountains supplied the public with usable water, Pope Paul V gifted the water of the Aqua Paola to nobility and other important individuals making sure they received the necessary amount to supply their own private villas, fountains, and gardens. The majority of the fountains found on the Aqua Paola Vatican branch led to private estates, including the Hospital of San Spirito, and only a handful of small public drinking fountains. ${ }^{81}$ The only large-scale public fountain found on this line was the Transpontina Vecchia, which was located on the main pilgrimage route from Ponte Sant'Angelo to Piazza San Pietro. This fountain plays an important ceremonial role while also providing drinking water for the pilgrims making their way to St. Peter's Basilica. ${ }^{82}$ Even though this line did not have much public utility, the ability of the Aqua Paola to provide water with enough volume and pressure to make all of the fountains fully functional is an unprecedented feat in urban design.

Unlike the Vatican branch of the Aqua Paola, the Janiculum branch is far more civic in nature because of the area it serves. (Figure 3.6) While the Vatican branch serves the pope, cardinals, and the nobility of the area, the Janiculum branch was made to provide water for the public. A significant fountain on this line accessible to the public is found in the piazza in front of the Church and Monastery of San Pietro in Montorio. This piazza, home to an order of Spanish Franciscans, was sponsored by King Ferdinand and Queen Isabella. In order to commemorate this aid from the Spanish monarchs, Giovanni Fontana designed the fountain that used to stand in the middle of the piazza. This new civic fountain was financed by Pope Paul V and decorated with images of the monarchs' families in a Spanish motif. ${ }^{83}$ The ornamentation found on the fountain was used specifically to remind the public who funded the piazza, while

\footnotetext{
${ }^{81}$ Rinne, The Waters of Rome, 143.

${ }^{82}$ Rinne, The Waters of Rome, 143.

${ }^{83}$ Rinne, The Waters of Rome, 149.
} 
the fountain itself was used as a constant reminder to the residents who provided this line of water supply.

Several pipes lead out to multiple areas, which further expanded the Aqua Paola's distribution in the area of Trastevere. The main conduit from the Spanish fountain turned south to service the area of Ripa Grande. ${ }^{84}$ The location of the port on the west bank of the Tiber was a chief reason for growth in Trastevere. A bustling population of working class people, such as boatmen, mill workers, laundresses, tanners, and wine-sellers, inhabited this area. ${ }^{85}$ The residents, industry, and commerce in this area relied heavily on daily water use, making the Aqua Paola an invaluable resource. Just as in ancient times, the area by the port housed certain waterintensive industries, such as potteries, brickwork, and tanneries, because of the area's proximity to the Tiber. ${ }^{86}$ These industries not only used the Tiber's water for their trade, but also preferred the urban periphery of Trastevere to that of the rural and relatively unpopulated Janiculum Hill, because of the pollutants their profession created. The Tiber was already a relatively unusable source of water because of the sewage and trash dumped in it, so the toxins and dyes added by these industries were not a problem and were seen as simply contributing to the Tiber's pollution.

Several different lines then spread out to expand the network, serving the port of Ripa Grande, the piazza in front of Santa Maria in Trastevere, and countless residents who had purchased water rights to the Paola water. ${ }^{87}$ To ameliorate the ancient problems of illegal tapping of the aqueduct's line, Pope Paul V allowed residents of Trastevere to purchase water rights. Many of the people buying these rights were not previous residents of the area, but

\footnotetext{
${ }^{84}$ Rinne, The Waters of Rome, 149.

${ }^{85}$ Grant Showerman, Eternal Rome, textbook ed. (New Haven: Yale University Press, 1924) 431.

${ }^{86}$ Taylor, Public Needs and Private Pleasures, 247.

${ }^{87}$ Rinne, The Waters of Rome, 149.
} 
instead new owners of building sites that were being constructed along Pope Paul V's new road, San Francesco. Since one of the Aqua Paola's many conduits ran underneath this street, the residents that built along it simply paid the Pope for right to the water and tapped into the line. This payment not only gave these owners easy assess to water, but also helped fund the construction of the Aqua Paola and its components.

With the construction of the Aqua Paola, Pope Paul V's ambitious urban development project was successful. It allowed for well-watered gardens in the Vatican, something that his predecessors only dreamed of provided a sufficient and ready supply of water to three different areas, improved the aesthetic view of the landscape by making two hills lush and green, and incorporated the western side of the Tiber into the existing network of aqueducts. In conjunction with this project, Pope Paul V designed twenty-five magnificent civic fountains, built countless other private fountains, helped revitalize and mold the region of Trastevere with his urbanistic ideals, and provided Rome with it own rebirth into the Baroque Period. ${ }^{88}$

\footnotetext{
${ }^{88}$ Rinne, The Waters of Rome, 154.
} 


\section{CONCLUSION THE END OF THE LINE}

Through researching, examining, and analyzing the Aqua Traiana, the Aqua Paola, and their components, this study has facilitated an understanding of the ways in which these two aqueducts, within their time periods, spatially, aesthetically, politically, demographically, and economically influenced the urban design of the area west of the Tiber.

Both of these aqueducts were exceptional feats of engineering in their planning, building techniques, and functionality; however, by the end of their construction, they symbolized more than their outward utilitarian architecture. Within their given time periods, these aqueducts impacted an entire region of Rome that had twice been cut off from the rest of the city because of its lack of a water supply and its location across the Tiber. Though the two aqueducts completely transformed this area by improving resident's hygiene, building up the industrial district, and beautifying the area, it was for personal and political gain of the rulers of Rome that water flowed into the city.

In Emperor Trajan's case, the Aqua Traiana was constructed in order to make sure there was a sufficient supply of water for his new bath complex. In ancient Rome, the bathing complexes were not only a place for exercise, but were more importantly used as a place for business and political discussions. Building an extravagant bath complex and constructing the new aqueduct that would supply said complex showed Trajan's supreme political power. While the people of Transtiberium were not the specific reason Trajan built his aqueduct, they significantly benefitted from its arrival in Rome. The social, demographic, economic, and aesthetic transformation that took place in the Transtiberium were also credited to Emperor Trajan and the water supply of the Aqua Traiana. For the many centuries it stood, the Aqua 
Traiana and its water remained a spectacular advertisement of Trajan's accomplishment in the city of Rome.

Similarly, Pope Paul V's main reason for revitalizing the Aqua Traiana in the form of the Aqua Paola was to provide the Vatican and the Borgo with their own supply of water. Pope Paul V specifically wanted to bring water back to revive the Vatican Gardens. Rejuvenating the garden was a symbol of the revitalization of Rome under his papacy. As with the Aqua Traiana, the Aqua Paola meant significant changes for the residents of Trastevere. The area improved in a similar fashion to its ancient predecessor, and Trastevere was transformed from a period of deterioration and turned into a bustling economic area for Rome, all because of the water supplied by the Aqua Paola. Thus, like monumental buildings, important roads, and large public spaces, water infrastructure has multiple functions behind its construction from political prowess, economic growth, to urban beautification.

This project also brings to light additional avenues of research in the field of Roman water. The first is approaching the same subject through a different lens. Because of the sources used in this thesis, this project focuses on the perspectives of Emperor Trajan and Pope Paul V, both individuals who had an unlimited amount of political power during their reign. Their points of view directly correlate to how this history was recorded. These same events would undoubtedly be different if told by the citizens of Rome. A second avenue of potential research is applying this method of analysis to the Aqua Vergine and Aqua Felice, the other two existing aqueducts that make up Rome's vast hydraulic network, and their ancient counterparts. Creating a dialogue across the centuries would uncover similarities in urban development of a particular area. The eastern side covered a larger swath of land boasting nine ancient aqueducts, which were condensed in the Renaissance to only two. The process presented in this project would 
provide a more widespread view of the development of the more populous region of Rome across those two centuries.

The Aqua Traiana and the Aqua Paola provided life to the area of Trastevere and provided an infrastructure on which Rome could expand to the west of the Tiber. Though this aqueduct line has largely been skipped over when discussing Rome's vast water system, this project sheds light on its contributions to Rome's layered history. 


\section{BIBLIOGRAPHY}

Aldrete, Gregory S. Daily Life in the Roma City: Rome Pompeii, and Ostia. Westport Connecticut: The Greenwood Press, 2004.

Anderson, James C., Jr. Roman Architecture and Society. Baltimore, Maryland: The Johns Hopkins University Press, 1997.

Archivio di Stato di Roma, Presidenza degli acquedotti urbani, 336/114: 79v, 8 OV- 8IR, and $92 \mathrm{~V}-93 \mathrm{R}$.

Aicher, Peter J. "Display Fountains ("Mostre") and the Aqueducts of Ancient Rome." Phoenix vol. 47, no. 4 (Winter, 1993): 339-352.

- Guide to the Aqueducts of Ancient Rome. Wauconda, Ill: Bolchazy-Carducci Publishers, 1995.

Ashby, Thomas. The Aqueducts of Ancient Rome. Washington: McGrath Pub. Co., 1973.

Bloch, Herbert. "Aqua Traiana" in American Journal of Archaeology vol. 48, no. 4 (Oct.-Dec., 1944): pp. 337-341.

Blunt, Anthony. Guide to Baroque Rome. London: Granada, 1982.

Brizzi, Bruno. Le Fontane Di Roma. Roma: Editore Colombo, 1987.

Buren, Albert William Van and Gorham Phillips Stevens. "The Aqua Traiana and the Mills on the Janiculum." Memoirs of the American Academy in Rome 1, (1915): 59-61.

BZOVIUS, Abrahamus. 1626. Paulus Quintus Burghesius. P.O.M. Ex typographia S. Paulini: Romæ.

Carcopino, Jérôme. Daily Life in Ancient Rome: The People and the City at the Height of the Empire. New Haven: Yale University Press, 1940.

Ceen, A., "Piranesi and Nolli: Imago Urbis Roman" in Piranesi: Rome Recorded, Catalog of the exhibition of Piranesi's Verdure di Roma at the Arthur Ross Gallery, University of Pennsylvania, 1989.

Cornell, Tim and Kathryn Lomas. Urban Society in Roman Italy. New York: St. Martin's Press, 1995.

Cosgrove, Denis E. and Geoffrey E. Petts. Water, Engineering, and Landscape: Water Control and Landscape Transformation in the Modern Period. London; New York: Belhaven Press, 1990. 
D'Onofrio, Cesare, and Max Dellacher. Le Fontane Di Roma: Con Documenti E Disegni Inediti. $2^{\text {nd }}$ ed. Roma: Staderini, 1962.

Davis, Raymond. The Lives of the Eighth-century Popes (liber Pontificalis): the Ancient Biographies of Nine Popes From Ad 715 to Ad 817. Liverpool: Liverpool University Press, 1992.

de Kleijn, Gerda. The Water Supply of Ancient Rome: City Area, Water, and Population. Dutch Monographs on Ancient History and Archaeology. Vol. 22. Amsterdam: Gieben, 2001.

Dill, Samuel. Roman Society: from Nero to Marcus Aurelius. New York: The Meridian Library, 1956.

Dyson, Stephen L. Community and Society in Roman Italy. Baltimore, Maryland: The Johns Hopkins University Press, 1992.

Faccioli, C. "Gio. Battista Nolli (1701-1756) e la sua gran Pianta di Roma del 1748," in Studi Romani, XVI (1966), pp. 415-442.

Forbes, S. Russell. The Aqueducts, Fountains and Springs of Ancient Rome. $3 \mathrm{~d}$ ed. Rome: Forbes?, 1899.

Frutaz, A.P. Le Piante di Roma, $2^{\text {nd }}$ and $3^{\text {rd }}$ vol., Roma, 1962.

Garbrecht, Günther. "Die Wasserbewirtschaftung römischer Thermen: archäologische und hydrotechnische Untersuchungen" ; DFG-Forschungsvorhaben Ga 183/29. Braunschweig: Leichtweiss-Inst, 1994.

Gasponi, Giancarlo, Rouhyeh Avaregan, Luciano Zeppegno, and Felicity Lutz. Rome, Water and Stone. Trento: Editoria. 1982.

Greenhalgh, Michael. Marble Past, Monumental Present: Building with Antiquities in the Mediaeval Mediterranean. Leiden; Boston: Brill, 2009.

Hodge, A. Trevor. Roman Aqueducts and Water Supply. London, England: Gerald Duckworth and Co., 1991.

Heilmann, Christoph H. "Acqua Paola and the Urban Planning of Paul V Borghese". The Burlington Magazine, 112 (811), 1970: 656-663.

"Il restaure della mostra dell'acqua paola al gianicolo" Comune di Roma, 2004.

Il Trionfo Dell'acqua: Acque E Acquedotti a Roma, Iv Sec. A.c. -xx Sec.: Mostra 31 Ottobre 1986-15 Gennaio 1987, Museo Della Civiltà Romana, Roma. Roma: Paleani, 1986. 
Karmon, David E. The Ruin of the Eternal City: Antiquity and Preservation in Renaissance Rome. Oxford; New York: Oxford University Press, 2011.

Lanciani, R. Forma Urbis Romae, Milano, 1893-1901.

Laurence, Ray and Joanne Berry. Cultural Identity in the Roman Empire. London; New York: Routledge, 1998.

Morton, H. V, and Mario Carrieri. The Waters of Rome. London: Connoisseur; Joseph, 1966.

Orbaan, Johannes Albertus Franciscus. La Roma di Paolo V negli Avvisi. Rome: Biblioteca Vallicelliana, 1920.

—. Documenti Sul Barocco In Roma. Roma: Società romana di storia patria, 1920.

Osborn, Robin. Studies in Ancient Greek and Roman Society. Cambridge, New York: Cambridge University Press, 2004.

Parkin, Tim G. Demography and Roman Society. Baltimore, Maryland: The Johns Hopkins University Press, 1992,

Parkins, Helen. Roman Urbanism: Beyond the Consumer City. London; New York: Routledge, 1997.

Partner, Peter. Renaissance Rome, 1500-1559: A Portrait of a Society. Berkeley: University of California Press, 1979.

Pinto J. "Nolli, Giovanni Battista," in Macmillan Encyclopedia of Architects, New York (1982): pp. 305-306.

—. "Orgins \& Development of the Ichnographic City Plan," in Journal of the Society of Architectural Historians, XXXV (1976): 35-50.

Ramsey, P. A. Rome In the Renaissance: the City and the Myth: Papers of the Thirteenth Annual Conference of the Center for Medieval and Early Renaissance Studies, State University of New York At Binghamton. Binghamton, N.Y.: Medieval and Renaissance Texts and Studies, Center for Medieval and Early Renaissance Studies, 1982.

Rinne, Katherine Wentworth. The Waters of Rome: Aqueducts, Fountains, and the Birth of the Baroque City. 1st ed. New Haven: Yale University Press, 2010.

“Rome's Lost Aqueduct. (Cover Story)." Archaeology 65, no. 2 (Mar, 2012): 34-40. http://search.ebscohost.com/login.aspx?direct=true\&db=rlh\&AN=71683636\&site=ehost$\underline{\text { live. }}$ 
Scott, Michael. Space and Society in the Greek and Roman Worlds. Cambridge, New York: Cambridge University Press, 2013.

Showerman, Grant. Eternal Rome. Text book ed. New Haven: Yale University Press, 1924.

Stambaugh, John E. The Ancient Roman City. Baltimore, Maryland: The Johns Hopkins University Press, 1992.

Symmes, Marilyn F, Kenneth A. Breisch, and Stephen Astley. Fountains: Splash and Spectacle: Water and Design From the Renaissance to the Present. New York: Rizzoli in association with Cooper-Hewitt, National Design Museum, Smithsonian Institution, 1998.

Taylor, Rabun, Katherine Rinne, Edward O'Neill and Michael O'Neill. “A Grotto-Shrine at the Headwaters of the Aqua Traiana." Journal of Roman Archaeology, Vol.23 (2010): 358371.

Taylor, Rabun. Public Needs and Private Pleasures: Water Distribution, the Tiber River and the Urban Development of Ancient Rome. Studia Archaeologica. Vol. 109. Roma: L'Erma di Bretschneider, 2000.

Torselli, Giorgio. Trastevere. Rome, Italy: Multigrafica Editrice, 1981.

Ward-Perkins, J. B. From Classical Antiquity to the Middle Ages: Urban Public Building In Northern and Central Italy Ad 300-850. Oxford [Oxfordshire]: Oxford University Press, 1984.

Wilson, Andrew. "Machines, Power, and the Ancient Economy." The Journal of Roman Studies, vol. 92, (2002): 1-32. 


\section{ILLUSTRATIONS}

\section{Introduction:}

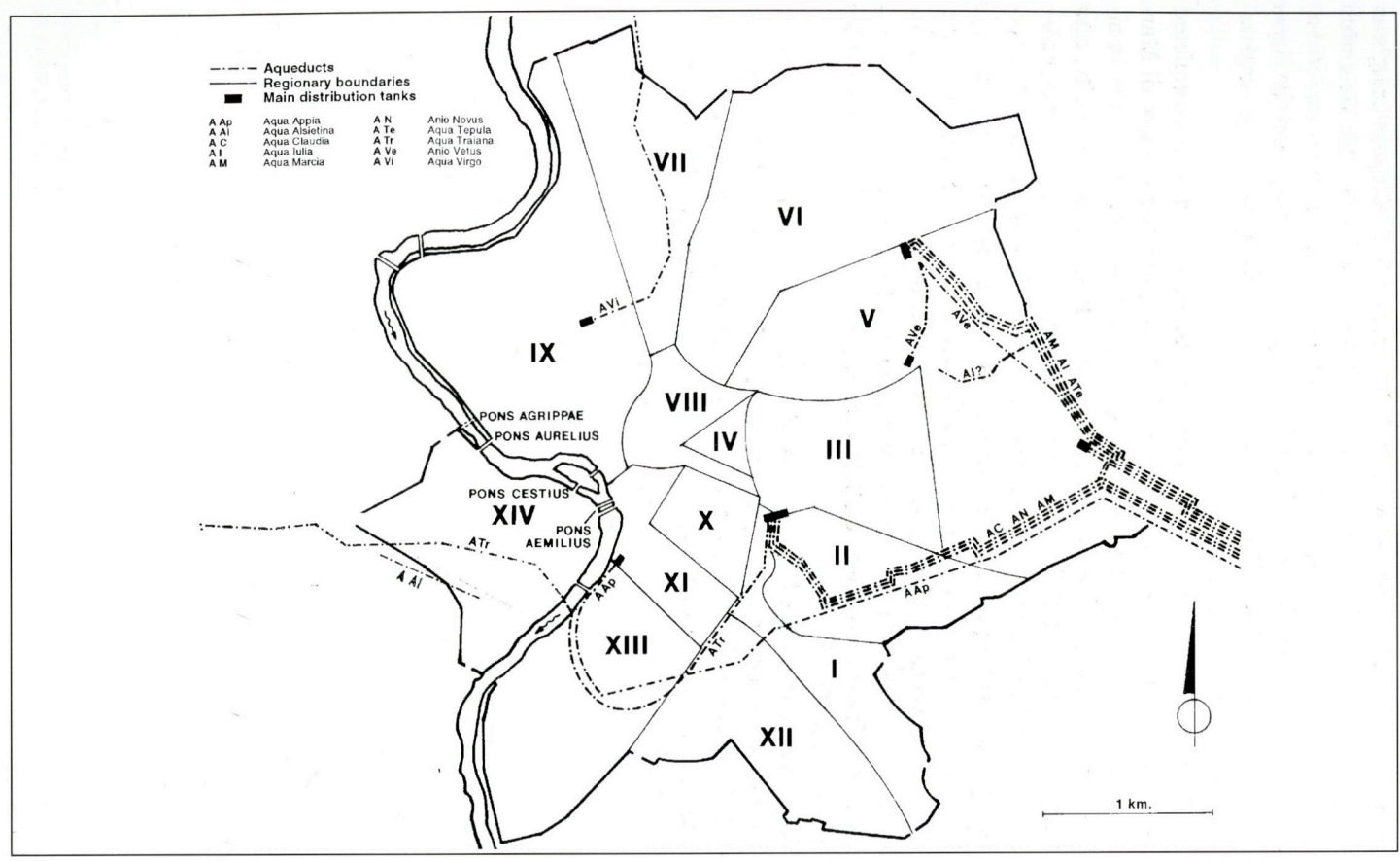

Figure i.1: General Map of Rome with aqueducts and regional division [Source: Taylor, Public Needs and Private Pleasures, 18.]
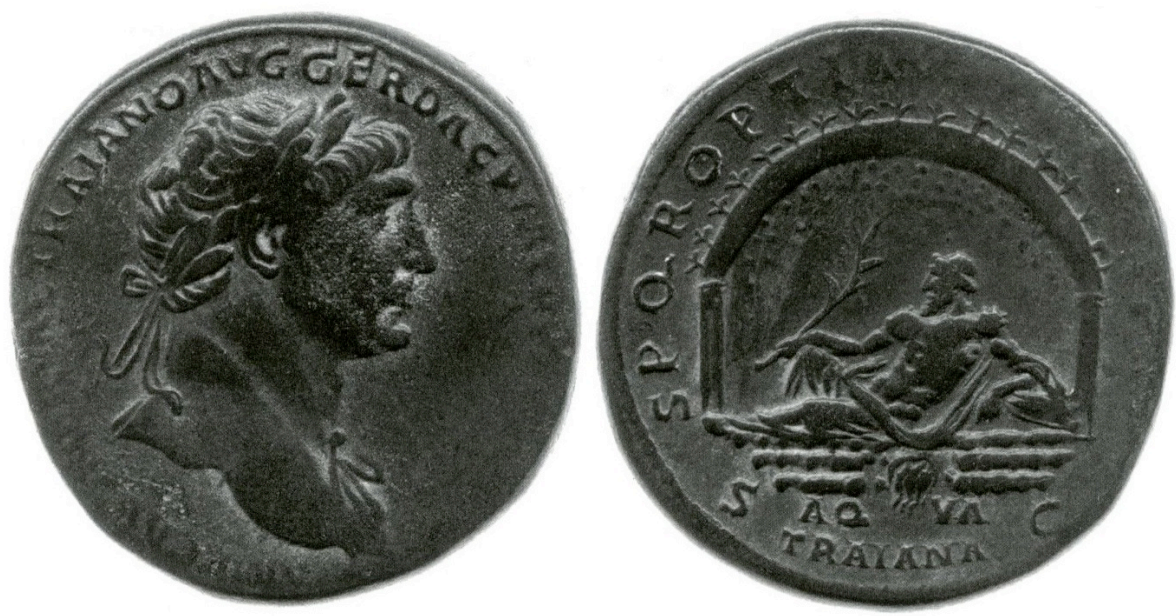

Figure i.2: Coin depicting the construction of the Aqua Traiana [Source: Taylor, Rabun, Katherine Rinne, Edward O'Neill and Michael O'Neill. "A Grotto-Shrine at the Headwaters of the Aqua Traiana." Journal of Roman Archaeology, Vol.23 (2010): 358.] 


\section{Chapter 1: Font of Knowledge}

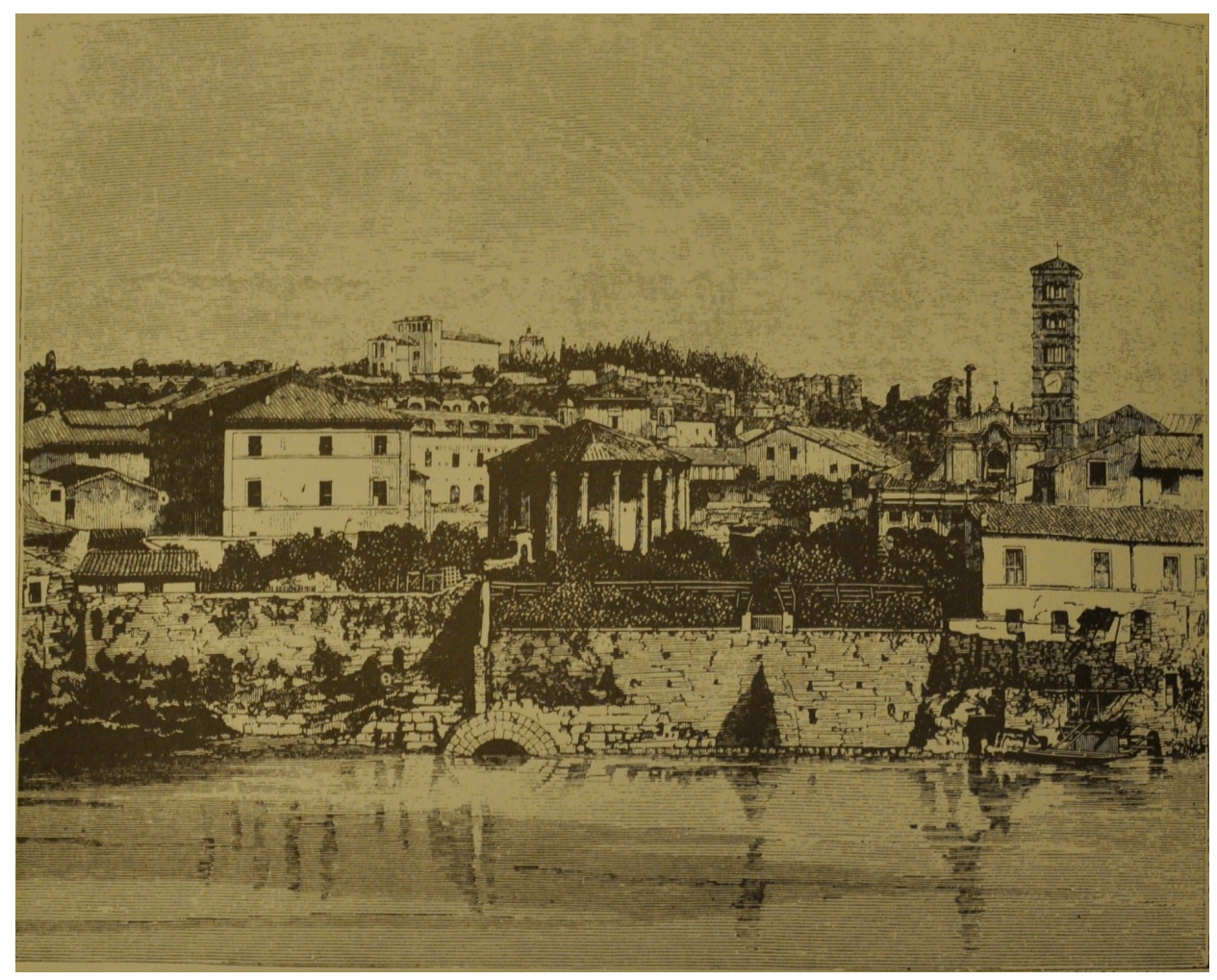

Figure 1.1: Nineteenth-century engraving of the Cloaca Maxima. The Exit drain into the river Tiber, still exists today, but is now partly hidden by the modern Lungotevere Embankment, is clearly visible [just below the round Temple of Vesta [Source Hodge, Roman Aqueducts and Water Supply, 71.]

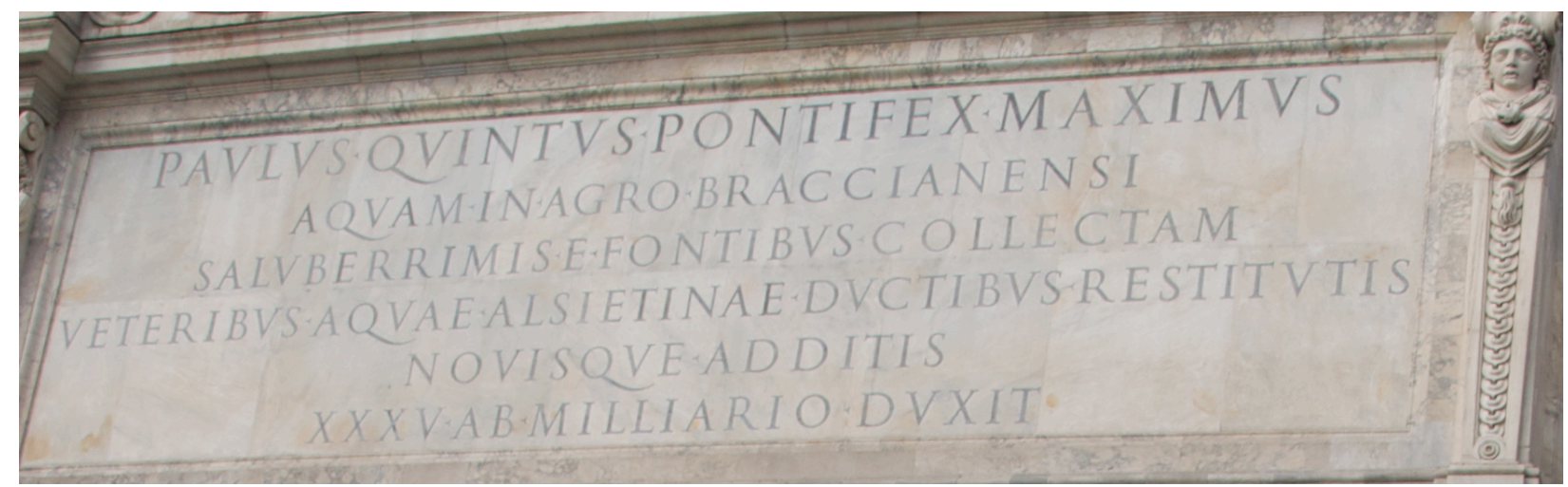

Figure 1.2: Aqua Paola Inscription [Photograph taken by author] 


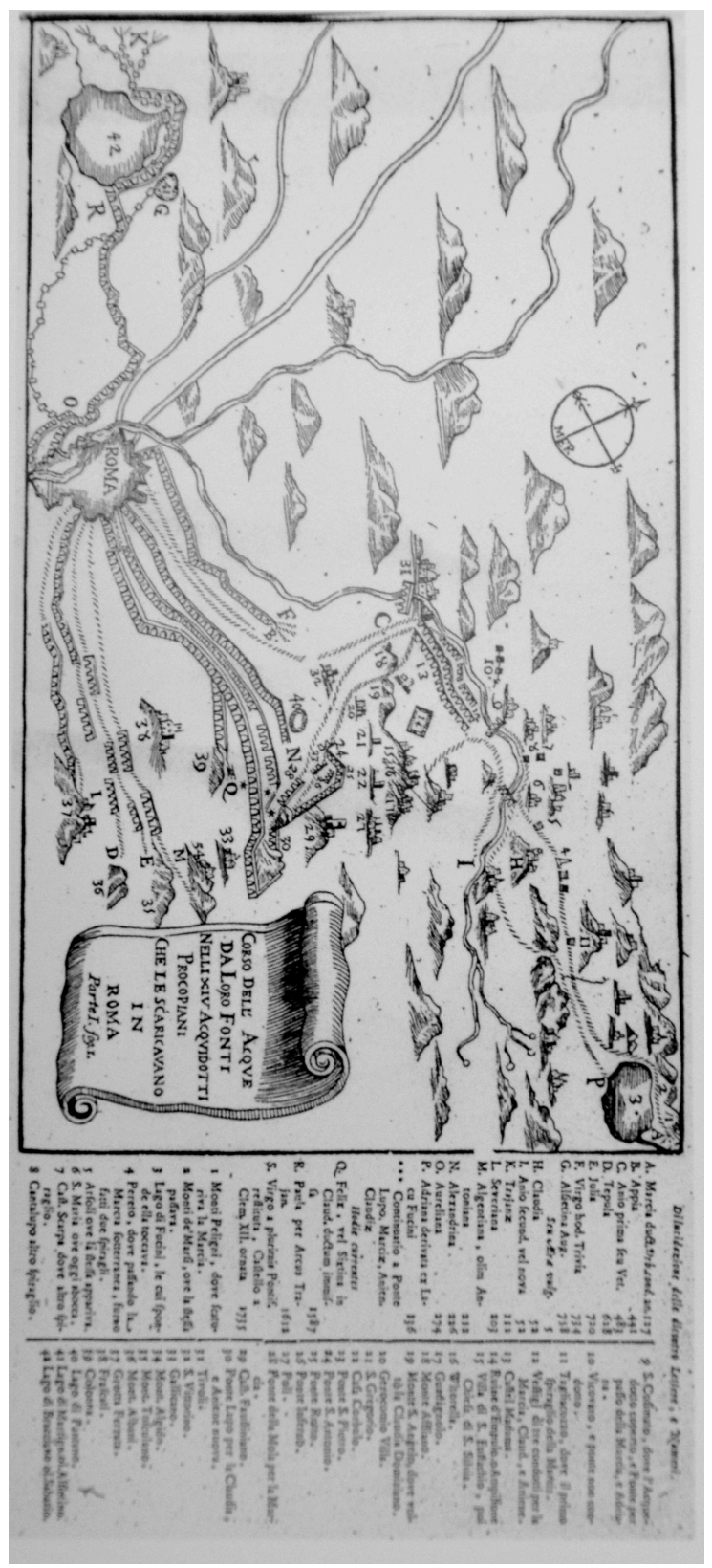

Figure 1.3: Route of the Aqua Traiana from Lake Bracciano [Source: Rinne, The Waters of Rome, 4.] 


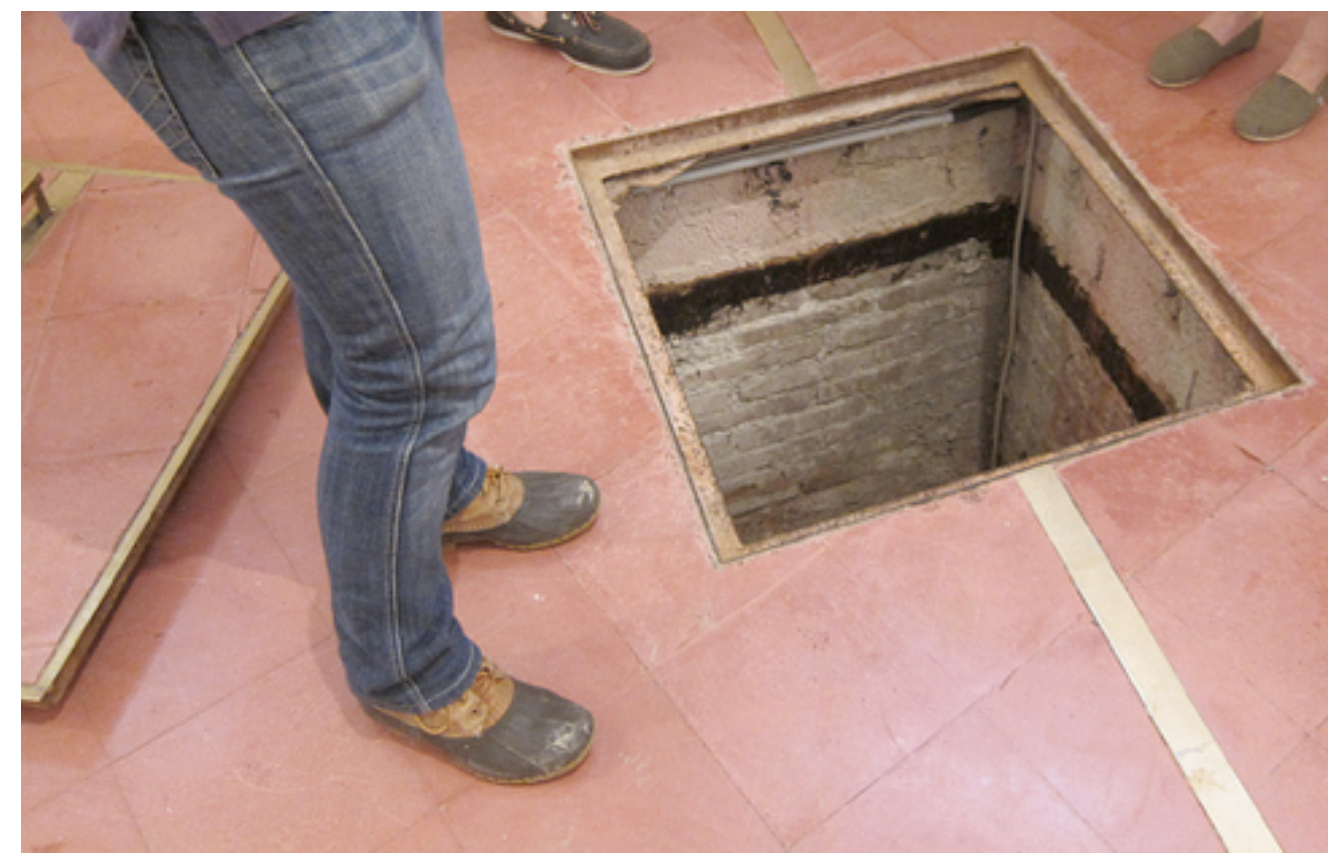

Figure 1.4: Entrance to the Aqua Traiana underneath the American Academy in Rome [Photograph taken by author] 


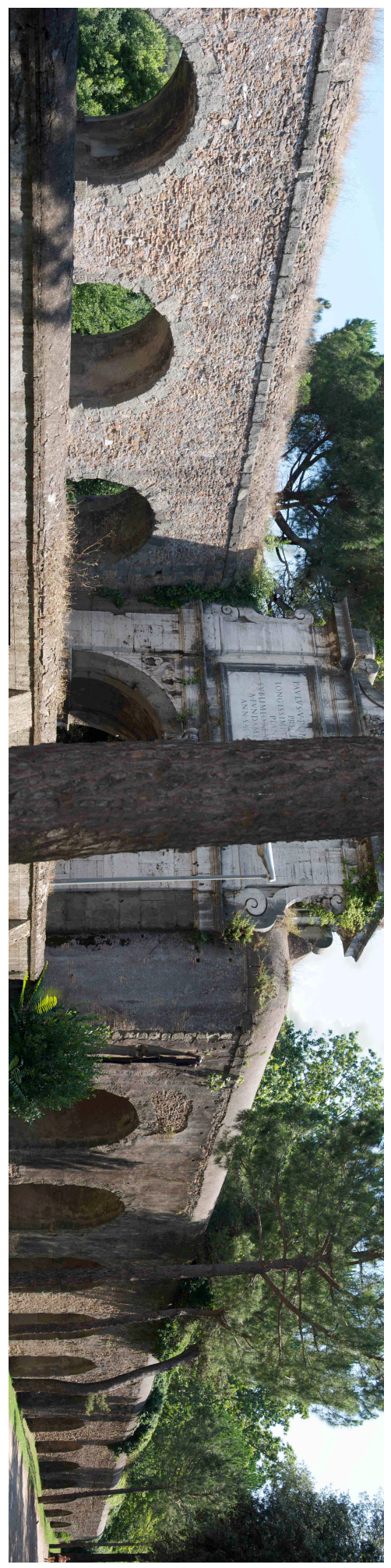

Figure 1.5: A section of remnants of the Aqua Traiana making of the northern boundary of Villa Doria Pamphili, along the Via Aurelia Antica [Photograph taken by author] 


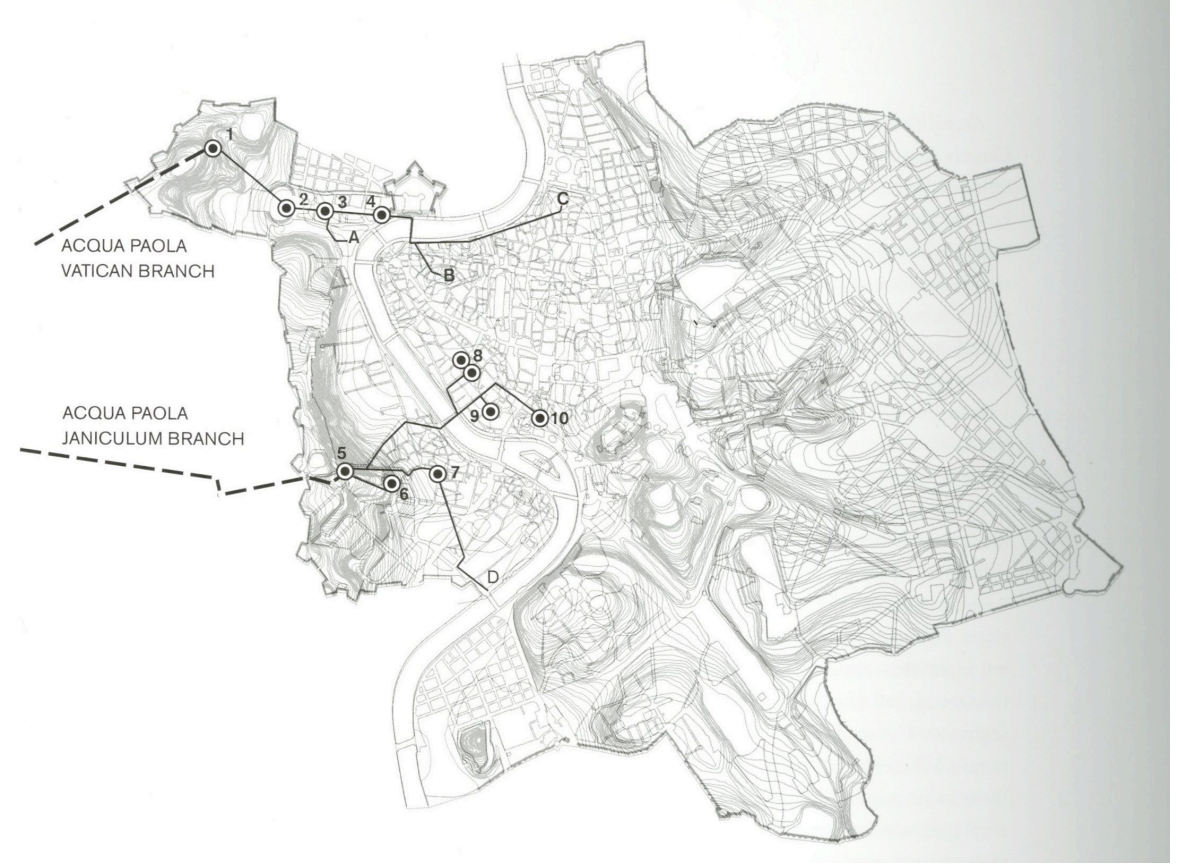

Figure 1.6: Detailed map of the two separate branches of the Aqua Paola [Source: Rinne, The Waters of Rome, 142.]

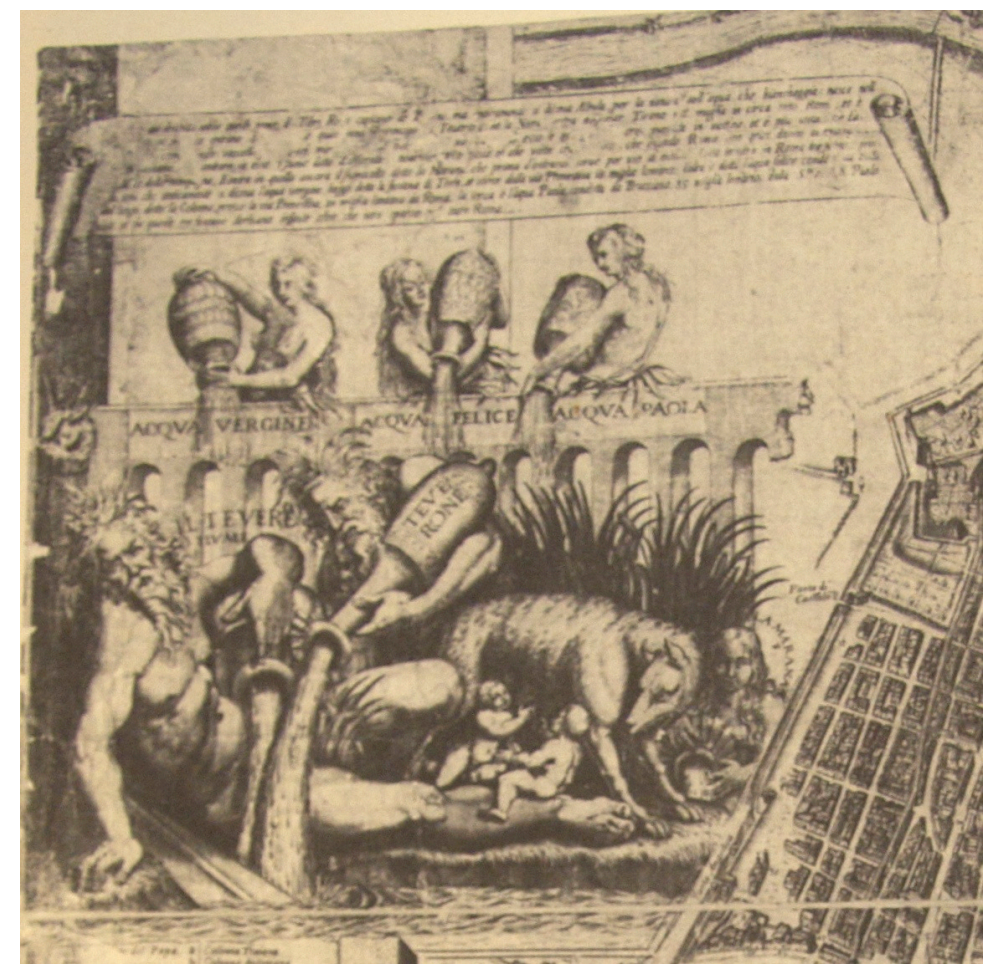

Figure 1.7: Detail of Matteus Greuter's 1618 Map of Rome [Source: Frutaz, A.P, Le Piante di Roma, $2^{\text {nd }}$ vol., Roma, 1962, Tav. 291.] 


\section{Chapter 2: Il Fontanone}

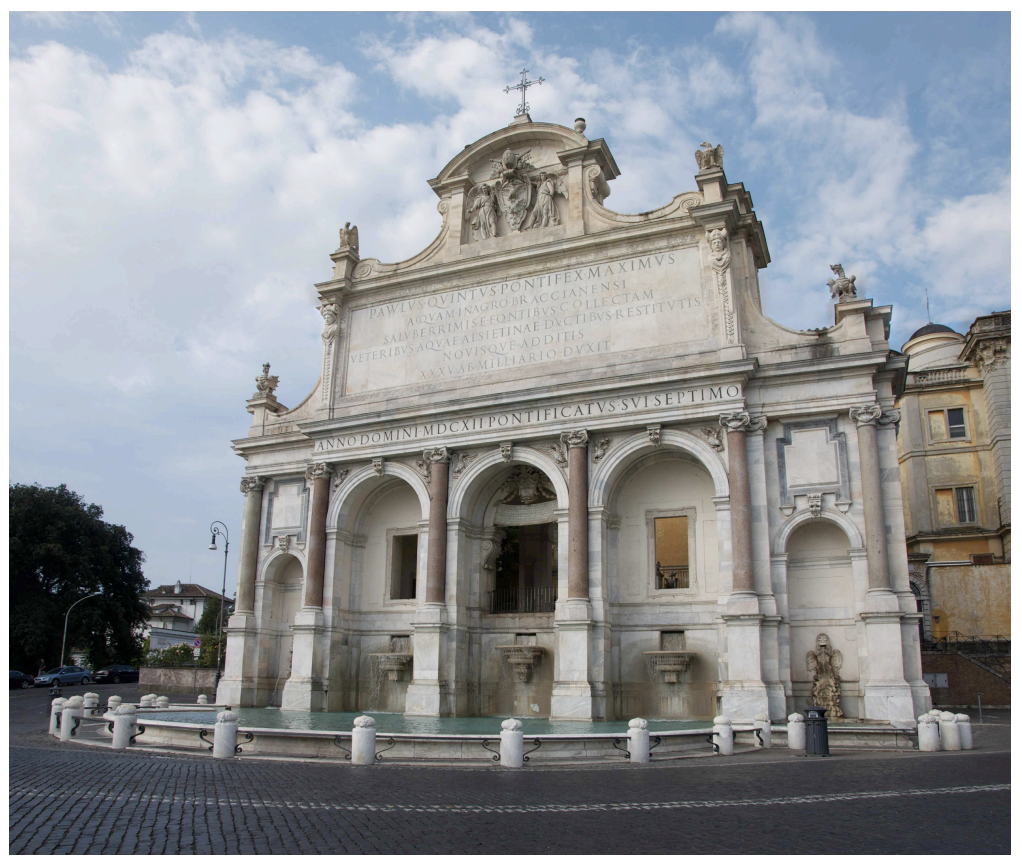

Figure 2.1: Aqua Paola's mostra fountain, Il Fontanone [Photograph taken by author]

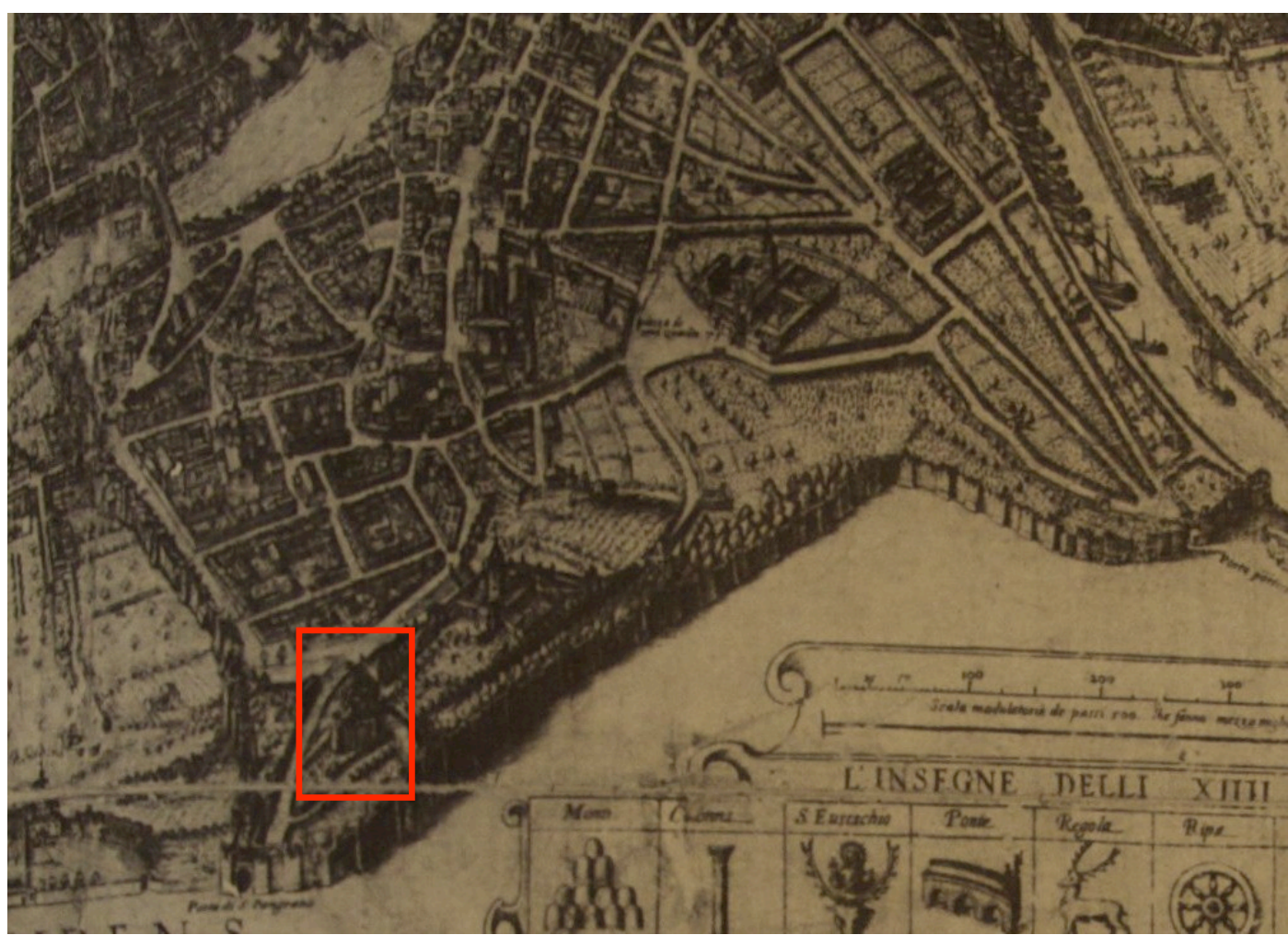

Figure 2.2: Detail of Matteus Greuter's 1618 Map of Rome documenting Il Fontanone (found in the red rectangle) [Source: Frutaz, A.P, Le Piante di Roma, $2^{\text {nd }}$ vol., Roma, 1962, Tav. 291.] 


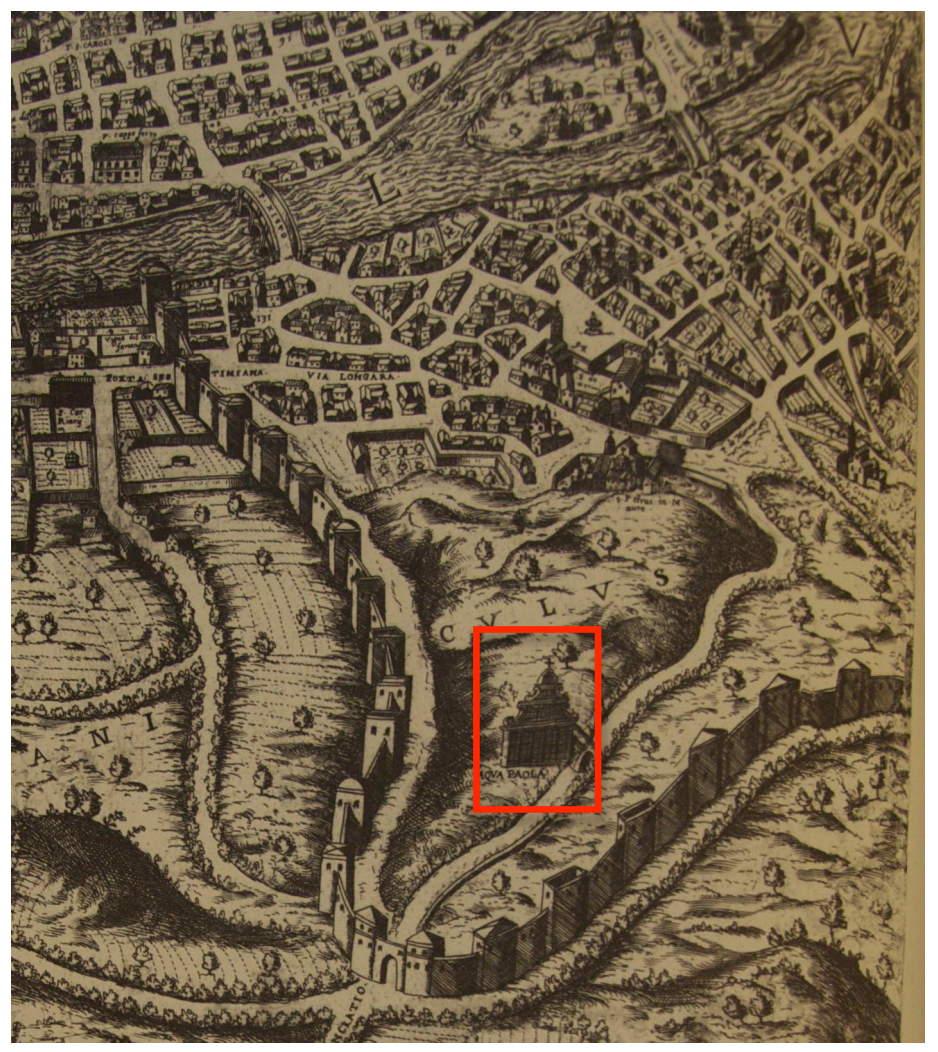

Figure 2.3: Detail of Francesco de Paoli's 1623 map of Rome documenting and labeling Il Fontanone (found in the red rectangle) [Source: Frutaz, A.P, Le Piante di Roma, $2^{\text {nd }}$ vol., Roma, 1962, Tav. 294.]

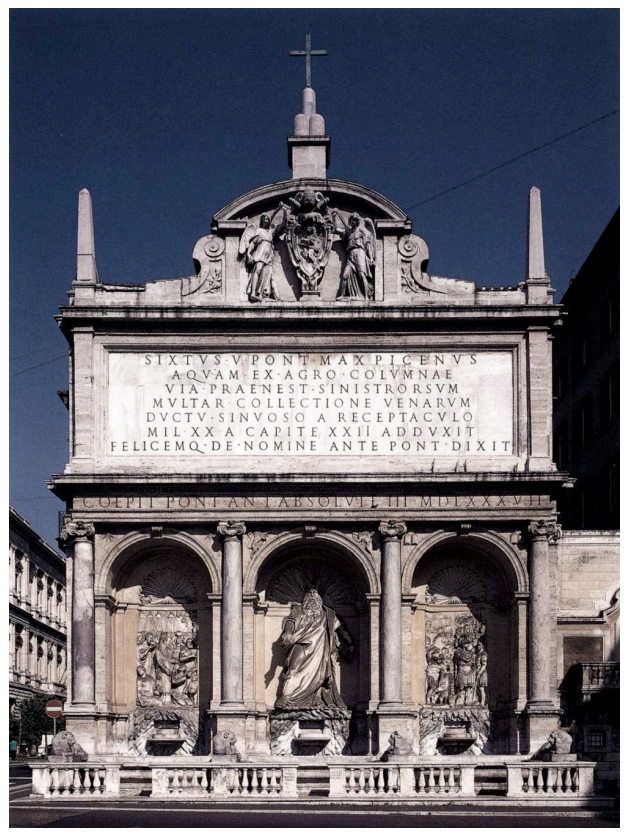

Figure 2.4: Fountain of Moses, designed by Domenico Fontana [Photograph taken by author] 

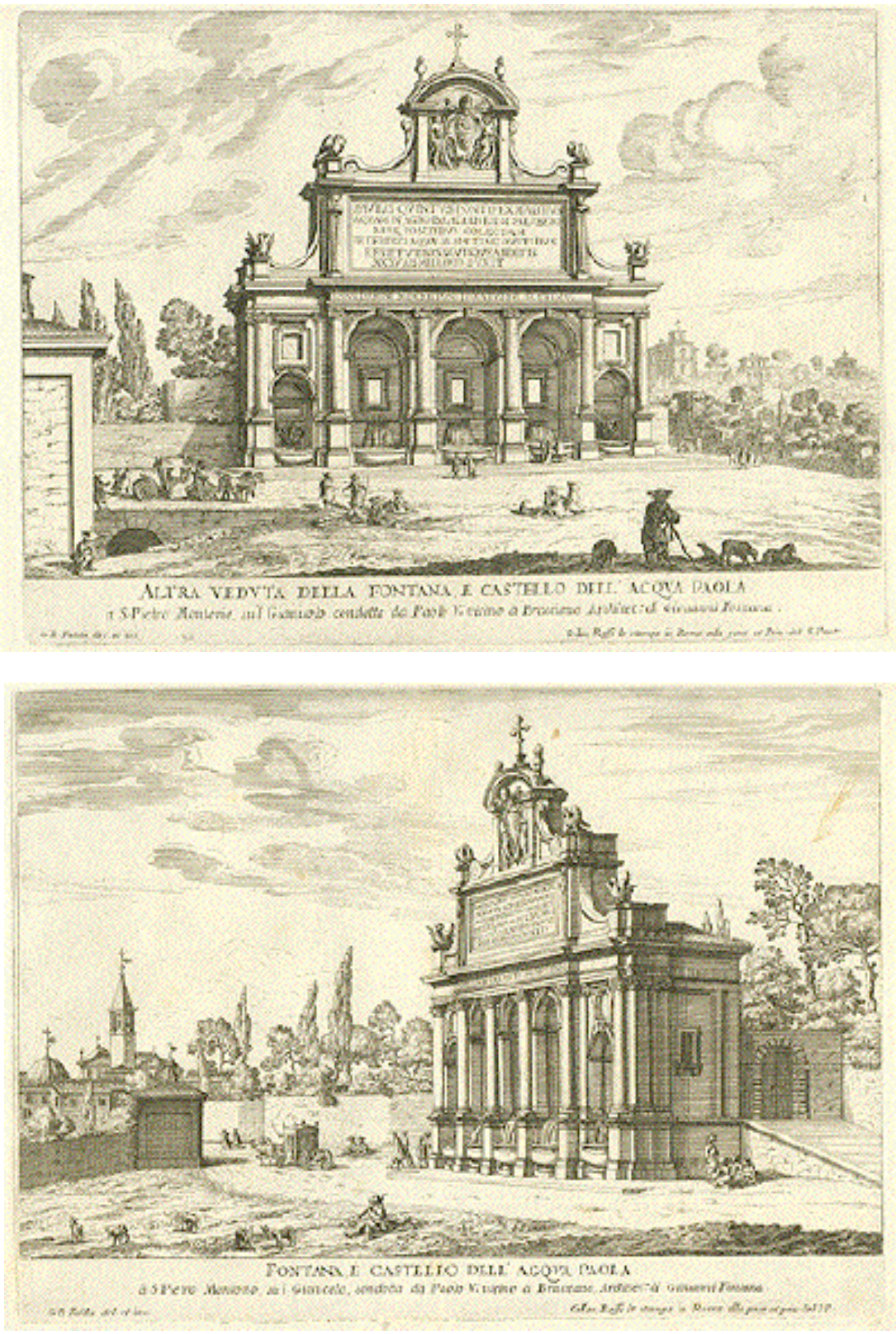

Figure 2.5: The original conception of the Fontanone, engravings by Giovanni Battista Falda [Source: Heilmann, “Acqua Paola and the Urban Planning of Paul V Borghese," 657.] 


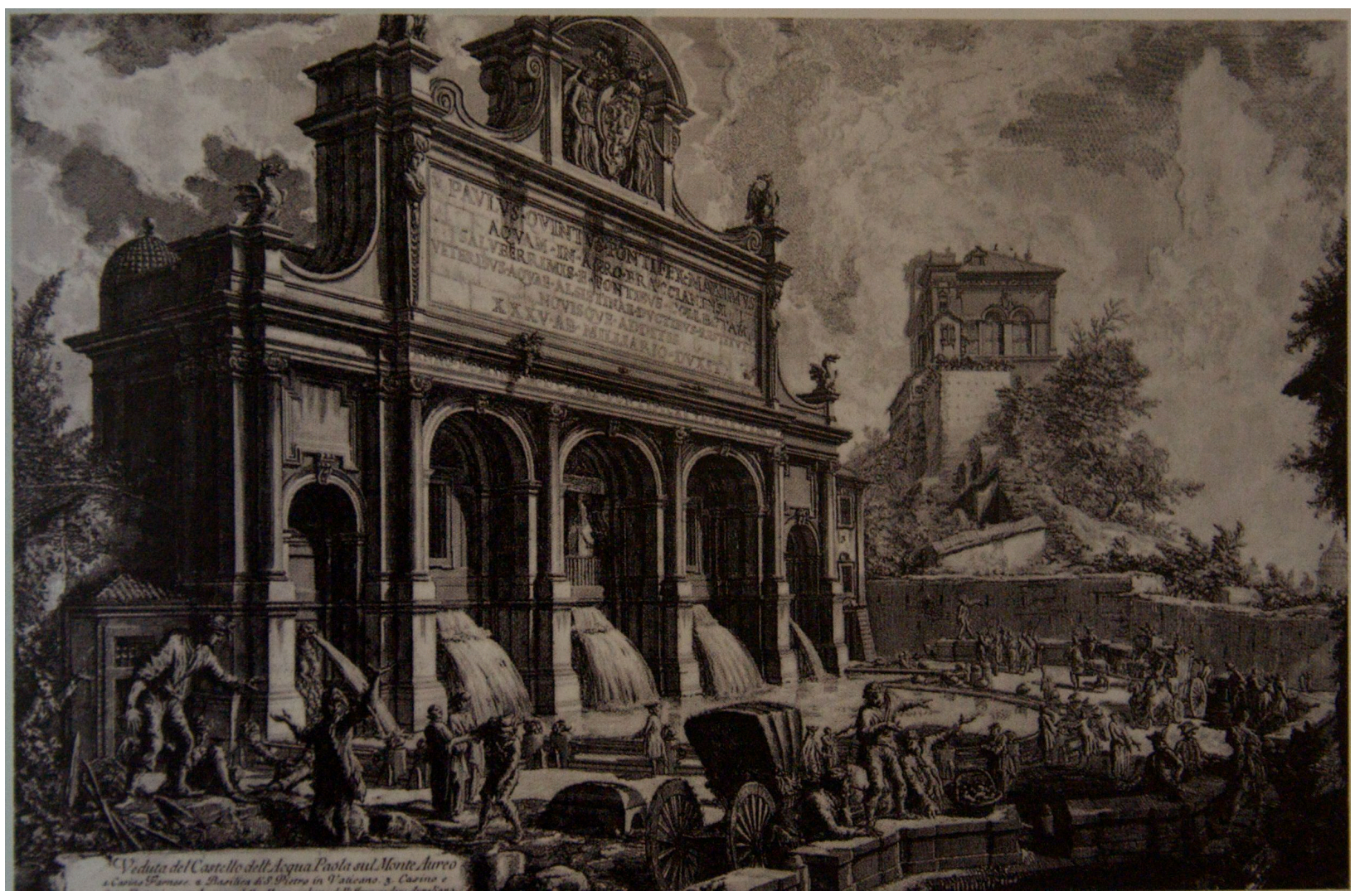

Figure 2.6: Il Fontanone as redesigned by Carlo Fontana in 1690 [Source: Symmes, Fountains: Splash and Spectacle, 37.] 


\section{Chapter 3: Urbanism in Seventeenth-Century Rome}

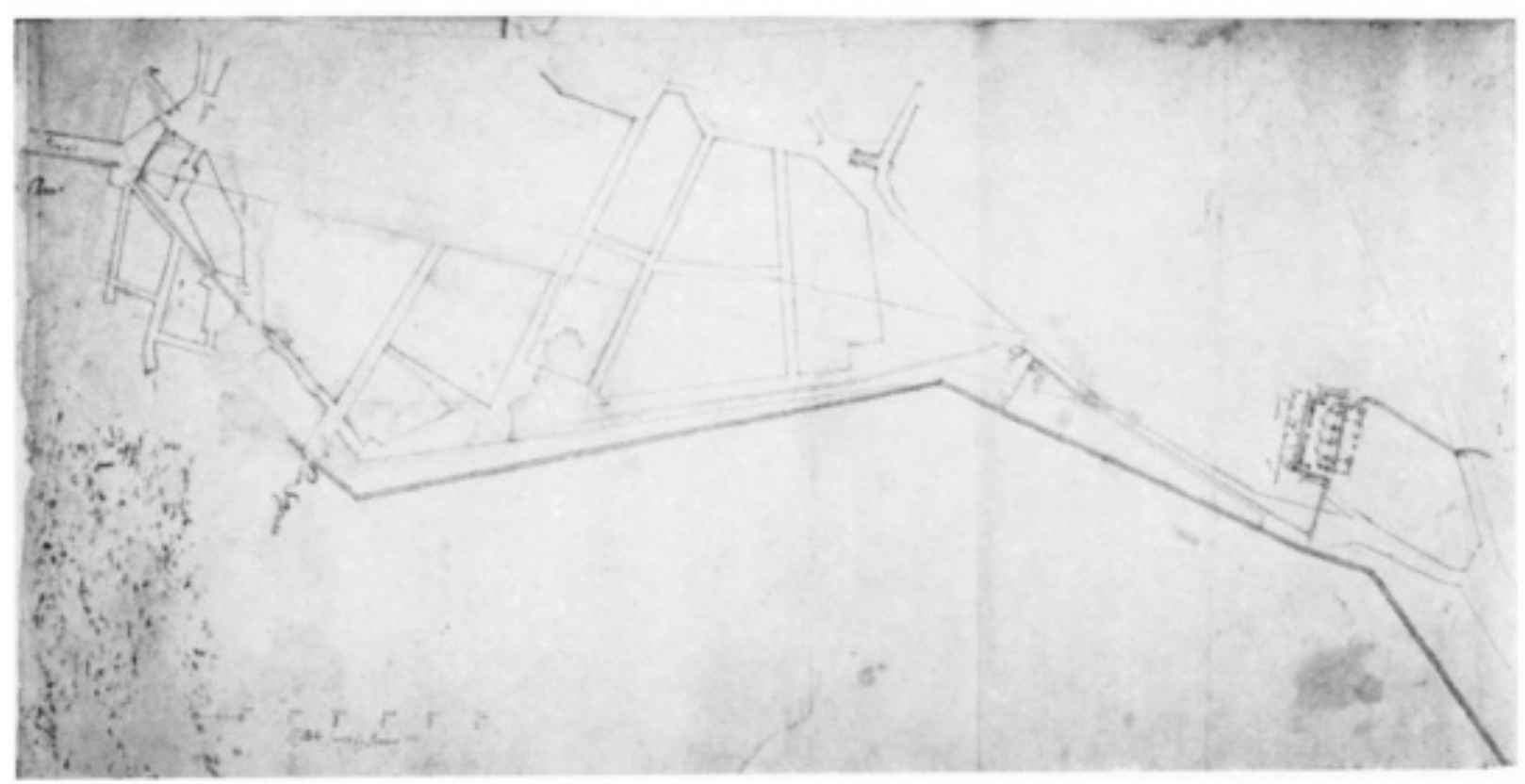

Figure 3.1: The original plan of the Aqua Paola's distribution system [Source: Heilmann, "Acqua Paola and the Urban Planning of Paul V Borghese," 663.]
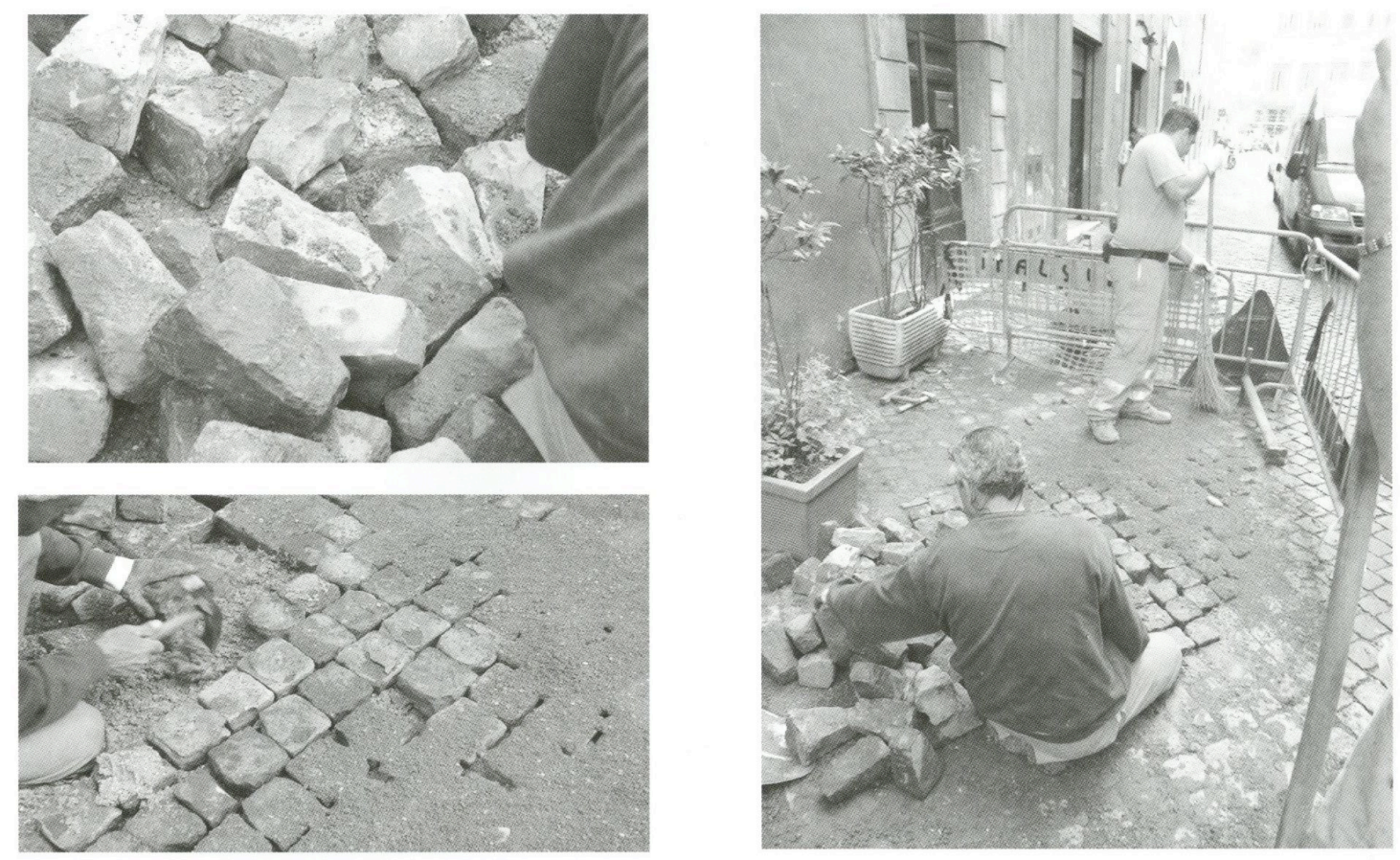

Figure 3.2: A modern day photograph of workers replacing sampietrini, they still utilize the road construction method from the Renaissance [Source: Rinne, The Waters of Rome, 209.] 


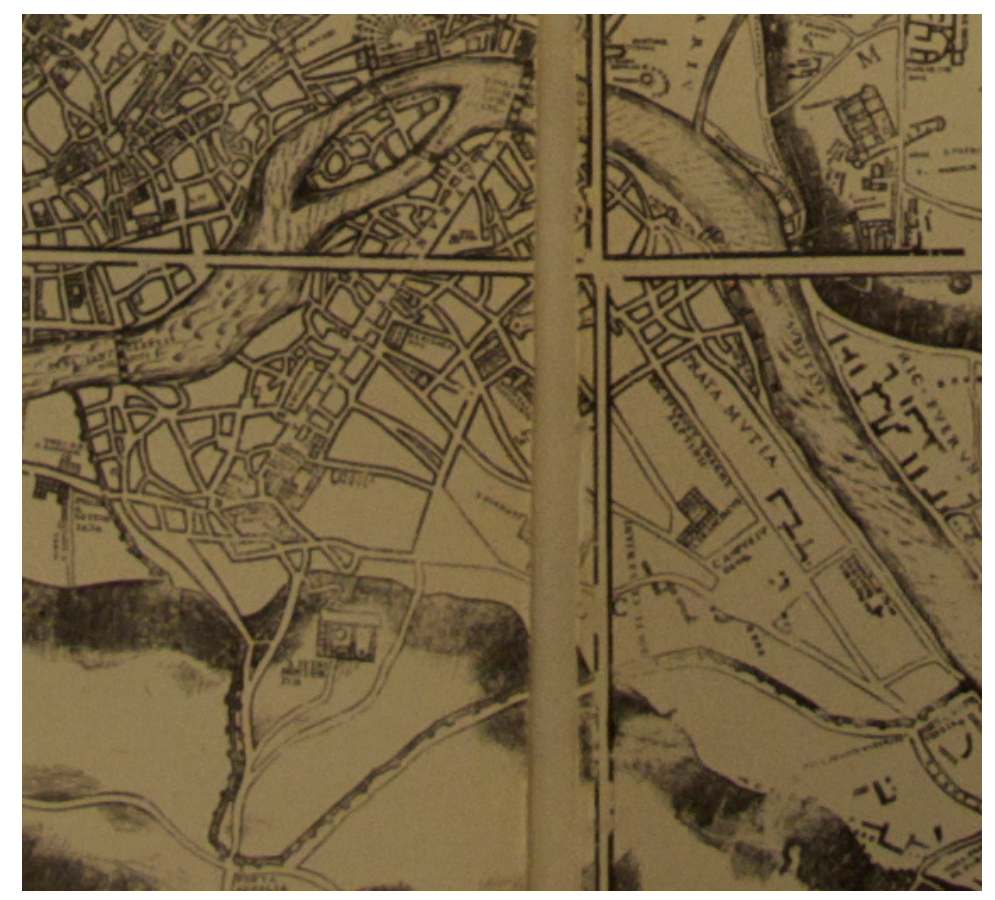

Figure 3.3: Leonardo Bufalini's map of Rome, 1551 (the area of Trastevere) [Source: Frutaz, A.P, Le Piante di Roma, $2^{\text {nd }}$ vol., Roma, 1962, Tav.169.]

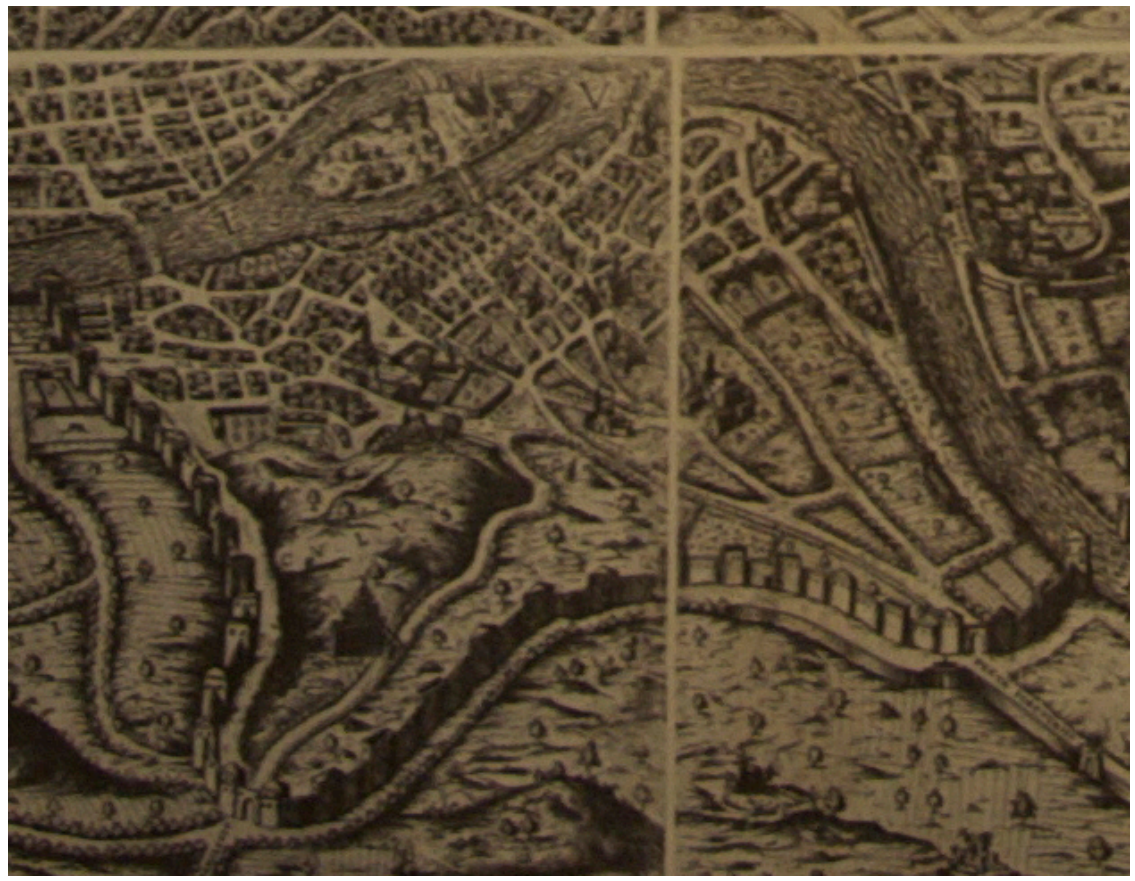

Figure 3.4: Francesco de Paoli's map of Rome, 1623 (the area of Trastevere) [Source: Frutaz, A.P, Le Piante di Roma, $2^{\text {nd }}$ vol., Roma, 1962, Tav. 294.] 

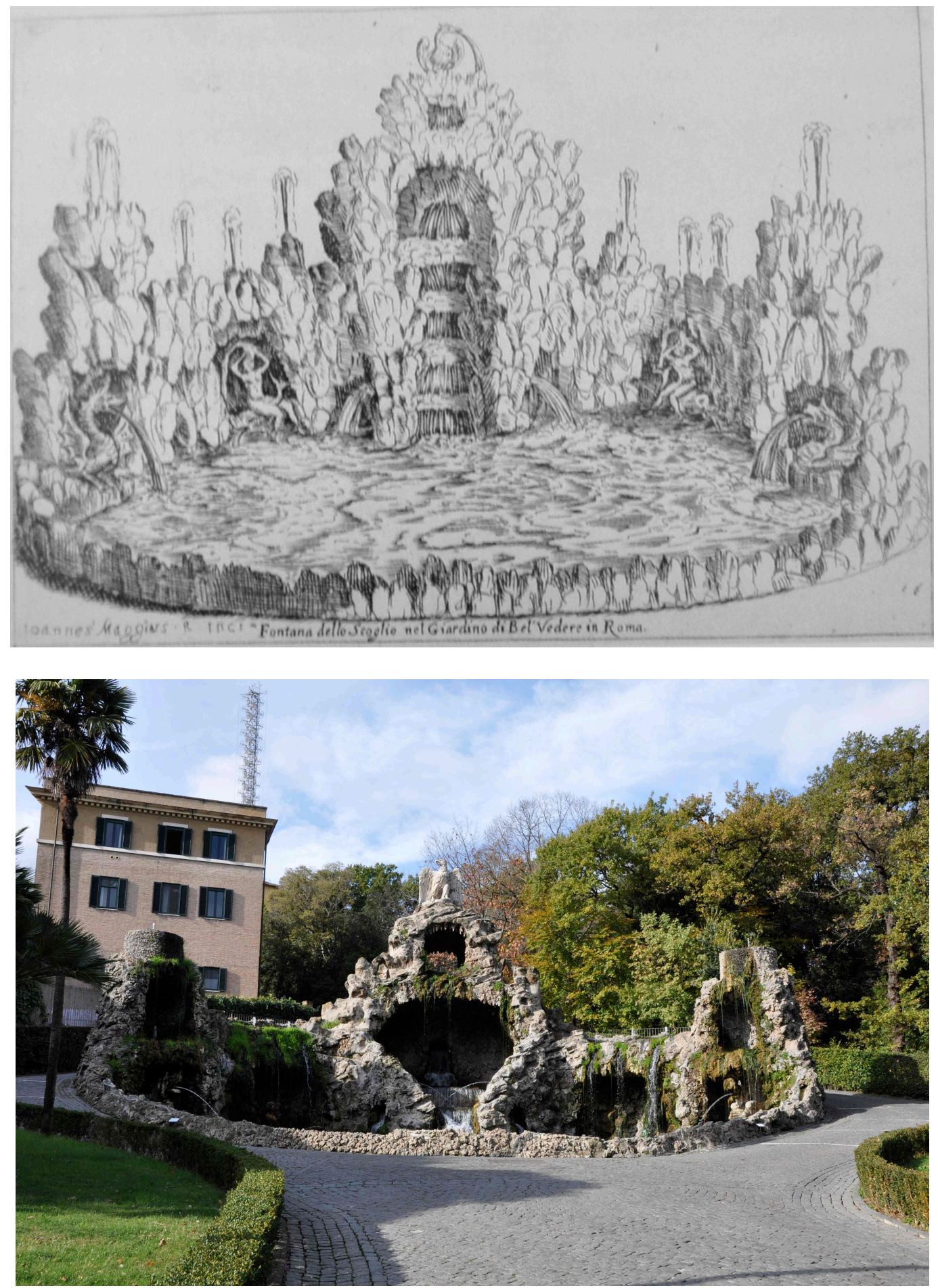

Figure 3.5: Etching of the Scoglio Fountain in the Vatican Garden [Top, Source: Rinne, The Waters of Rome, 142]

Modern day picture of the fountain in the Vatican Gardens [Below, photograph taken by author's sister, Sara Mess] 


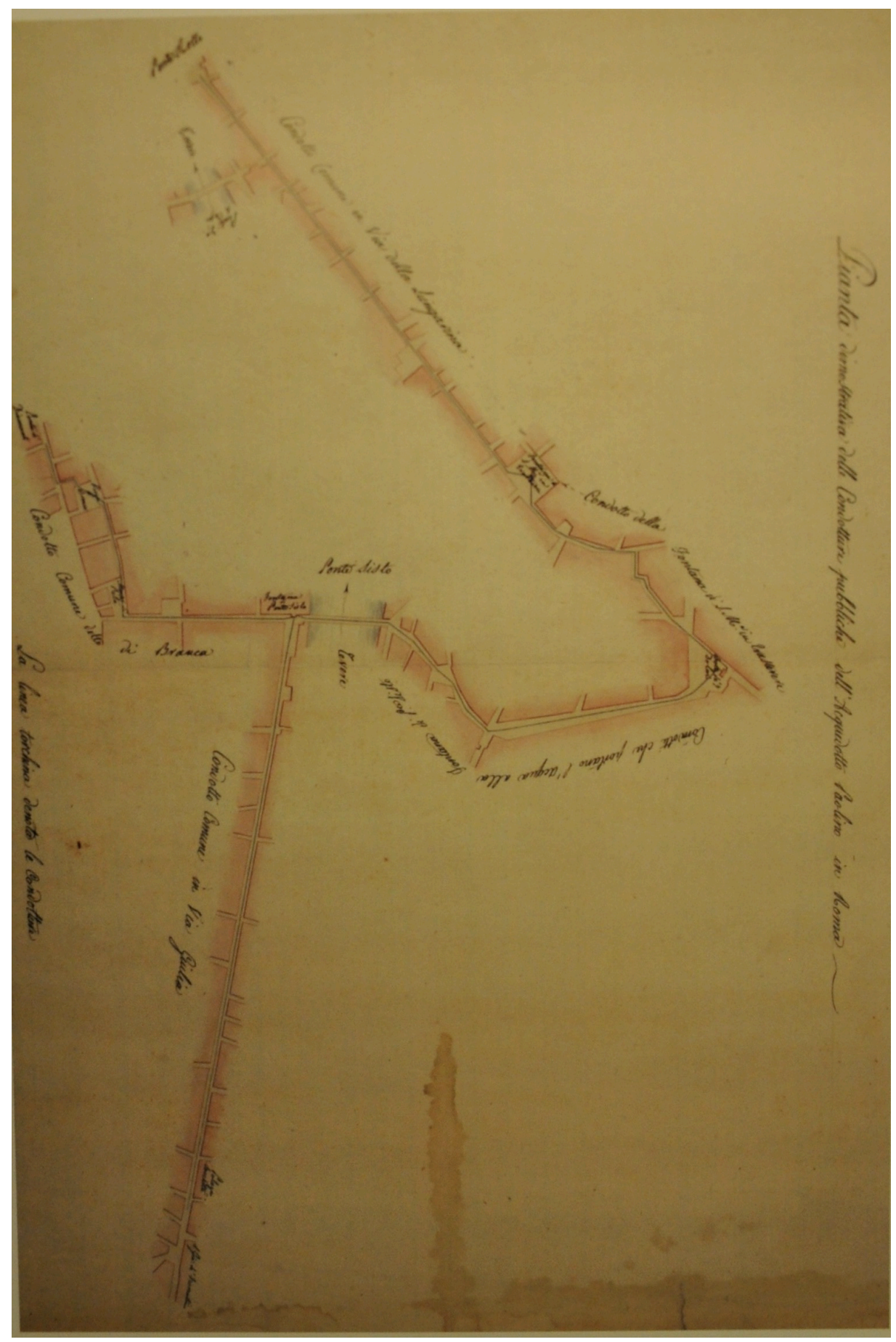

Figure 3.6: Route of the Aqua Paola's Janiculum Branch [Source: Rinne, The Waters of Rome, 151.] 